\title{
Economic evaluation of alternative technologies to mitigate Sulphur emissions in maritime container transport from both the vessel owner and shipper perspective
}

\author{
Seyed Abolfazl Mohseni*, Edwin van Hassel, Christa Sys and Thierry Vanelslander
}

\author{
* Correspondence: Seyedabolfazl. \\ mohseni@uantwerp.be \\ Department of transport and \\ regional economics, University of \\ Antwerp, Prinsstraat 13, 2000 \\ Antwerp, BE, Belgium
}

\begin{abstract}
International maritime shipping is confronted from 2006 onwards with regulation until 2030 by different policy actors (i.e. International Maritime Organization, hereafter $\mathrm{IMO})$, the EU) in order to improve the ecological performance of maritime shipping, and will face more so in the future. Many of these regulations concern the reduction of air pollution of vessels both globally and in particular in so-called Emission Control Areas (ECA's).

In this research, the economic impact of alternative technologies in order to reduce the Sulphur emissions in existing ECA zones is analyzed both from the perspective of the vessel owner, as well as for the evaluation of generalized chain cost, hence from the shipper point of view.

The container carriers can choose different methods to comply with the new regulations, such as switching fuel types (Liquefied Natural Gas (LNG), Marine Diesel Oil (MDO)) or opting for innovative technologies like installing scrubber systems. The goal of this research is twofold: first, to discover alternative available technologies to mitigate Sulphur emissions according to the literature; second, to evaluate economically the selected technologies both from vessel owners and shippers perspectives.

In order to study this, an update of an existing model is used. The added value of the extended model is threefold: calculating the generalized chain cost of transporting a container from the origin (US and Asia) to a destination in the EU, incorporating in the model the different ECA zones in the world and integrating more detailed fuel cost calculations and capital cost for different engine types or technologies used.

The methodology used in this research is an extension of an existing model which is updated for the purpose of this research. This update includes a new functionality to allow calculating the vessel owner cost for different fuel types and propulsion systems (Heavy Fuel Oil or HFO, MDO and LNG). Next to that, more maritime distance data is collected containing the distance sailed in ECA zones. This means that for each port-to-port combination, in the total maritime distance database in the model, this additional information is added. Based on this information, the fuel cost can be calculated when a vessel is sailing in ECA zones using either MDO, LNG or HFO (including a scrubber).

(Continued on next page)
\end{abstract}


(Continued from previous page)

The research is particularly interesting for logistics operators, legislation regulators and academia. The extended model allows calculating the best economic solutions for selected routes. For logistics operators and in particular for shippers, the results allow making the most rewarding investments from an economic point of view and affirm the importance of different technologies on the generalized chain cost. The results indicate that the price of the different fuels (and the spread between them) displays an important factor in the overall outcome.

Keywords: Alternative fuels, LNG propulsion, Scrubber system, Marine diesel oil, ECA zones, Maritime cost, Chain cost

\section{Introduction}

The transport sector is one of the biggest energy consumers, resulting in over $26.6 \%$ of total energy consumption globally and 33\% in Europe, and as a result, it is one of the biggest air polluters with a continuing growth projected by the European Commission (Žaglinskis et al. 2018). Shipping is responsible for $90 \%$ of international transport and in 2017, freight rates improved across all markets, with the exception of tankers. The container freight market improved considerably. Global container demand grew by $6.4 \%$ in 2017, taking total shipped volumes to an estimated 148 million TEUs. Moreover, global dry bulk trade grew by about $4 \%$ in 2017, bringing total volumes to 5.1 billion tons. However, Crude oil seaborne trade expanded at a slower pace $-2.4 \%$ in 2017 - compared with stronger growth - 4\% - in 2016 (UNCTAD 2019).

International marine shipping is a large contributor to Nitrogen Oxide $\left(\mathrm{NO}_{\mathrm{x}}\right)$ and Sulphur Oxide $\left(\mathrm{SO}_{\mathrm{x}}\right)$ emissions, representing a share of $13 \%$ and $12 \%$ of global emissions respectively (IPCC 2013; Stevens et al. 2015) and according to IMO estimates, in 2012, greenhouse gas (GHG) emissions from international shipping accounted for $2.2 \%$ of anthropogenic carbon dioxide $\left(\mathrm{CO}_{2}\right)$ emissions. Moreover, emissions from shipping due to the burning of the Sulphur content of marine fuels contribute to air pollution in the form of $\mathrm{SO}_{\mathrm{x}}$ and particulate matter (Sys et al. 2015).

Relevant regulations have been considered under the auspices of IMO, including the adoption in 2011 of a set of technical and operational measures to reduce emissions from international shipping and related guidelines (UNCTAD 2011; UNCTAD 2012). In April 2018, IMO adopted an initial strategy to reduce annual greenhouse gas emissions from ships by at least $50 \%$ by 2050 , compared with 2008 - a particularly important development. With regard to air pollution, the global limit of $0.5 \%$ on Sulphur in fuel oil used on board ships will come into effect on January 1st, 2020 (UNCTAD 2019). This means that the maximum level of pollution of $\mathrm{SO}_{\mathrm{x}}$ and $\mathrm{NO}_{\mathrm{x}}$ globally and in particular within Emission Control Areas (ECA's) is set (IMO 2011; McGill et al. 2013).

ECA's are sea areas in which stricter controls are established to minimize airborne emissions from ships as defined by Annex VI of the 1997 MARPOL Protocol. Within ECA's in which more stringent controls on $\mathrm{SO}_{\mathrm{x}}$ emissions apply, the Sulphur content of fuel oil must be no more than $0.1 \%(1000 \mathrm{ppm})$ from January 1st, 2015. According to UNCTAD (2019), with regard to ship-source air pollution, the global limit of $0.5 \%$ on Sulphur in fuel oil outside ECA's will come into effect on January 1st, 2020. The first two Sulphur Oxide ECA's were established in Europe, in the Baltic Sea and the North Sea, and took effect in 2006 and 2007, respectively; the third was established in North 
America and took effect in 2012; and the fourth was established in the United States Caribbean Sea, covering waters adjacent to the coasts of Puerto Rico and the United States Virgin Islands, and took effect in 2014 (UNCTAD 2019). The current and possible future US and European ECA zones are plotted in Fig. 1.

According to GARD (2018), in September 2015, China's Ministry of Transport released its Ship and Port Pollution Prevention Special Action Plan (2015-2020), a fiveyear program that aims to reduce $\mathrm{SO}_{\mathrm{x}}$ and $\mathrm{NO}_{\mathrm{x}}$ emissions by up to $65 \%$ in some of China's major ports. The subsequent publication of a Chinese regulation designating the Pearl River and Yangtze River Deltas, and the Bohai-rim Waters as ECA's places a cap on the Sulphur content of fuel oil in the ECA's at $0.50 \%$ and is considered an important step to achieve these pollution prevention goals. Eleven ports within the ECA's are designated "key ports":

- Shenzhen, Guangzhou, and Zhuhai in the Pearl River Delta

- Shanghai, Ningbo-Zhoushan, Suzhou, and Nantong in the Yangtze River Delta

- Tianjin, Qinhuangdao, Tangshan, and Huanghua in the Bohai-rim Waters

From January 1st, 2017, ships calling at the 11 key ports must use fuel with a Sulphur content not exceeding $0.50 \%$ whilst berthed. From January 1st, 2018, the requirement will be extended to all ports located within the ECA's.

van Hassel et al., (van Hassel et al. 2016a, 2016b) study the establishment of the ECA's at the North Sea and how these ECA's could offset the competitive position of the Hamburg - Le Havre (HLH) range ports to the Mediterranean ports. In the study, vessel owners opt to use MDO in order to mitigate pollutants in the ECA's in the North Sea. The same authors analyzes two different routes: one from Asia to the EU and one from South America to the EU. From the performed analysis, van Hassel et al., (van Hassel et al. 2016a, 2016b) conclude that the competitive position of the HLH ports is not affected by the establishment of the ECA's. Moreover, it was also found that the impact differs per route.

In the present research, the focus of the analysis shifts from the port range to the vessel owner and the shipper viewpoint. The main purpose of this research is to determine which

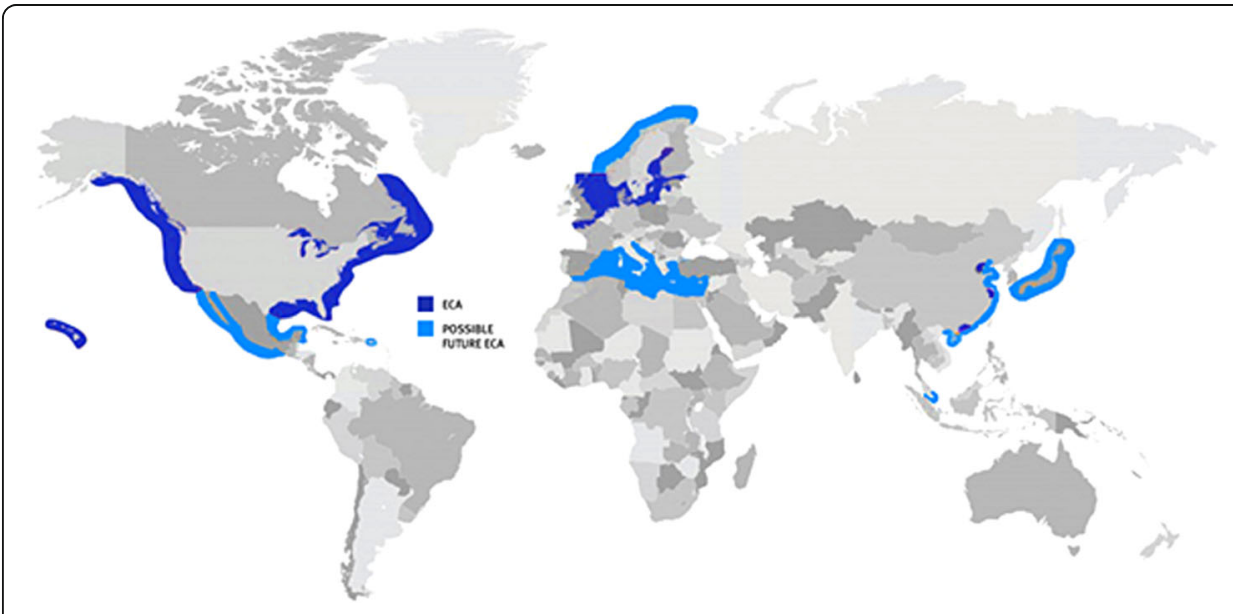

Fig. 1 Current and possible future ECA's. Source: http://www.kolbia.org (Kolbia 2019) 
of all the available options to comply with the ECA regulation is economically most suitable for the vessel owner and the shipper. The research questions that will be investigated are:

- What are the best alternative options to comply with the ECA regulation according to the literature?

- Of those selected technologies, what are the maritime costs from a vessel owner point of view and what is the impact of new technology on the generalized chain cost?

In the pages that follow, three alternative fuels or technologies are considered: Marine Diesel Oil (MDO), Liquefied Natural Gas (LNG) and scrubber technology. Based on alternative fuel used inside and outside ECA's, three diverse scenarios are discussed with two different maritime routes: one from Asia to Europe and the second one from the US to Europe, with different ship sizes for each maritime route.

In order to answer these two research questions, a two-step approach is used. In the first step, an extensive literature study is conducted to determine which alternatives are the most suitable to use. In the second step, for the selected alternatives, a cost modeling approach is applied. Following van Hassel et al. (van Hassel et al. 2016a, 2016b), this analysis uses a model designed for both calculating the total vessel owner cost as well as the generalized cost of transporting a container from an origin to a destination. It can simulate both the total vessel owner cost as well as the generalized cost of a supply chain for transporting goods from a point in hinterland A (for instance in the US) to another point in hinterland B (for instance in Europe). To study the impact of the implementation of the considered, implemented technologies to fulfill to the new types of legislation, this model will be extended with more detailed maritime distance data (ECA distances) as well as a more detailed cost calculation which includes the three above-mentioned options. In addition, external costs of pollutants such as $\mathrm{SO}_{\mathrm{x}}, \mathrm{NO}_{\mathrm{x}}$, $\mathrm{CO}_{2}$, and PM are considered in the calculation.

This paper is structured along the following parts. Section 2 reports the literature review regarding available alternative fuel options and economic comparison of different technologies is reported. Section 3 discusses the modeling methodology. Section 4 provides an overview of the collected data and explains the details of scenarios, maritime routes and vessel sizes taken into consideration for each scenario. Section 5 reports the results obtained for total maritime cost and chain cost. Finally, the last section outlines the main outcomes and conclusions.

\section{Literature review}

The literature review is structured into four sub-sections. Firstly, a short overview of the main legislation literature is given. Here, the main focus will be on the ECA zones and Sulphur reduction legislation. Secondly, the different alternative fuels are analyzed, while in the third section, the Exhaust Gas Treatment Systems are examined. The last section gives an overview of the selected fuels and technologies that will be further analyzed.

\section{Emission legislation}

Different international organizations (i.e. IMO) and institution policies impose international environmental standards on their member states to limit the emission of 
greenhouse gases (Sys et al. 2015). International maritime legislation is shifting towards lower levels of permitted exhaust gas Sulphur oxide emissions from ships (Lahtinen 2016). The regulation stems from concerns about "regional and global air pollution and environmental problems" in regard to the shipping industry's contribution. In July 2010, a revised and more stringent Annex VI was enforced in the Emission Control Areas with significantly lowered emission limits (McGill et al. 2013). Based on the literature, there are some emission legislations for international shipping in order to reduce $\mathrm{SO}_{\mathrm{x}}$ and $\mathrm{NO}_{\mathrm{x}}$ pollutants. New and existing regulations derived from the International Convention for the Prevention of Pollution from Ships (MARPOL) affecting the $\mathrm{SO}_{\mathrm{x}}$ emissions from ships are summarized in Table 1.

Inside ECA areas, limits for $\mathrm{SO}_{\mathrm{x}}$ and PM are reduced from 1\% (since July 1st, 2010) to $0.10 \%$, effective from January 1st, 2015. Moreover, the Sulphur content of any fuel used on board a ship must be reduced to 0.5\% from January 1st, 2020 (IMO 2011; Stevens et al. 2015; McGill et al. 2013). In addition, to meet the fuel Sulphur limits in Table 1, ships operating in the ECA areas must respect the MARPOL Annex VI Marine Tier III $\mathrm{NO}_{\mathrm{x}}$ limits in 2016. Table 2 shows the applicable $\mathrm{NO}_{\mathrm{x}}$ limits for ships and the dates that they became or will become effective. (IMO 2011; McGill et al. 2013; Perera and Mo 2016).

From Table 2, it is clear that the legislation values rely on the rated engine speeds (n) given in RPM (revolution per minute). The $\mathrm{NO}_{\mathrm{x}}$ legislation applies to diesel engines $(>130 \mathrm{~kW})$ installed on a ship constructed on or after January 1st, 2000 and prior to January 1st, 2011 for Tier I, while Tier II applies to diesel engines (>130 kW) installed on a ship constructed on or after January 1st, 2011 and Tier III is for diesel engines $(>130 \mathrm{~kW})$ installed on a ship constructed on or after January 1st, 2016. It should be mentioned that Tier I and Tier II limits are global, whereas Tier III standards apply only in the $\mathrm{NO}_{x}$ ECA's (IMO 2011; McGill et al. 2013).

IMO and EU policies require ship operators to reduce the Sulphur emissions of their ship operations. Ships operating in a Sulphur Emission Control Area (SECA) need to use distillate fuels in these regions, or a technology that can reduce emissions to an equivalent level, as of January 1st, 2015. There are several options available to comply with the new limits, including Marine Gas Oil (MGO), LNG and Heavy Fuel Oil (HFO) and scrubber (den Boer and Hoen 2015). According to Semolinos et al., (2013), vessel owners have only three realistic alternatives to achieve compliance with the $\mathrm{SO}_{\mathrm{x}}$ regulations: using MDO, installing scrubbers on board the ships, or convert ships to run on LNG. To meet the $\mathrm{NO}_{\mathrm{x}}$ regulations, only an LNG solution will, in theory, comply with

Table 1 MARPOL Annex VI marine $\mathrm{SO}_{x}$ emission reduction areas with fuel Sulphur limits

\begin{tabular}{llll}
\hline Sulfur Emission Control Areas & Year & Fuel Sulfur (\%) & Fuel Sulfur (ppm) \\
\hline North Sea, English Channel & Before 2015 & 1 & 10,000 \\
\multirow{3}{*}{ Baltic Sea } & As of 2015 & 0.1 & 1,000 \\
& Before 2015 & 1 & 10,000 \\
United States, Canada & As of 2015 & 0.1 & 1,000 \\
& Before 2012 & 1 & 10,000 \\
Global & As of 2015 & 0.1 & 1,000 \\
& Before 2012 & 3.5 & 35,000 \\
& As of 2020 & 0.5 & 5,000 \\
\hline
\end{tabular}

${ }^{a}$ Alternative date is 2025 , to be decided by a review in 2018 Source: Own composition based on (IMO 2011; McGill et al. 2013) 
Table 2 MARPOL Annex $\mathrm{VI} \mathrm{NO}$ x emission limits

\begin{tabular}{lllll}
\hline & & & \\
\cline { 3 - 5 } Year & Tier & $\mathrm{n}<130$ & $130 \leq \mathrm{n}<2000$ & $\mathrm{n} \geq 2000$ \\
\hline 2000 & Tier I & $17 \mathrm{~g} / \mathrm{kWh}$ & $45 \mathrm{n}^{-0.2} \mathrm{~g} / \mathrm{kWh}$ & $9.8 \mathrm{~g} / \mathrm{kWh}$ \\
2011 & Tier II & $14.4 \mathrm{~g} / \mathrm{kWh}$ & $44 \mathrm{n}^{-0.23} \mathrm{~g} / \mathrm{kWh}$ & $7.7 \mathrm{~g} / \mathrm{kWh}$ \\
$2016^{\mathrm{a}}$ & Tier III & $3.4 \mathrm{~g} / \mathrm{kWh}$ & $9 \mathrm{n}^{-0.2} \mathrm{~g} / \mathrm{kWh}$ & $1.96 \mathrm{~g} / \mathrm{kWh}$ \\
\hline
\end{tabular}

an NOx emission control areas (Tier II standards apply outside ECA's)

Source: Own composition based on (IMO 2011 and McGill et al. 2013)

Tier III. Ships will need to install systems to reduce $\mathrm{NO}_{\mathrm{x}}$ (like selective catalytic reduction (SCR) systems) if running on MDO or HFO in any case.

\section{Alternative marine fuels}

The use of HFO as a marine fuel poses serious environmental and economic risks (Roy and Comer 2017). In 2013, McGill et al. stated that the large part of the marine fuel consumption (approximately 77\%) is of low-quality, low-price residual fuel also known as heavy fuel oil, which tends to be high in Sulphur. With stricter emission rules and more public focus on maritime transport, reducing emissions in a cost-efficient way has become a necessity for shipping lines (Lindstad et al. 2015). Market penetration by alternative fuels has already begun with shipbuilders, engine manufacturers and classification bodies by introducing greener ships running on cleaner fuels (Moirangthem and Baxter 2016).

There are growing numbers of shipboard applications of new, alternative fuels such as low-Sulphur fuels, gas fuels, and biofuels in the global maritime transport (Kolwzan and Narewski 2012). Aronietis et al. (2015) state that there are three approaches in order to avoid $\mathrm{SO}_{\mathrm{x}}$ in shipping. The first approach is to use Sulphur-free fuels which can be done through some alternative options; the first alternative is the usage of the more expensive MDO with a low-Sulphur content but also with lower viscosity, while the second alternative is using LNG as a fuel. The second approach is to remove the Sulphur from the exhaust gasses by continuing to use the cheap HFO and clean the exhaust gasses on board by means of a scrubber. The third approach is to reduce the required fuel volume. An example of this is optimizing the Power Take Off (PTO) on the main gearbox.

The alternative fuels that are most commonly considered today are LNG, Electricity, Biodiesel, and Methanol. Other fuels that could play a role in the future are Liquefied Petroleum Gas (LPG), Dimethyl Ether (DME), Biomethane, Synthetic fuels, Hydrogen (particularly for use in fuel cells), Hydrogenation-Derived Renewable Diesel (HDRD) and Pyrolysis Oil. Additionally, fuels such as Ultra-Low-Sulphur Diesel (ULSD) can be used to comply with the regulations and support the transition to alternative fuels (Moirangthem and Baxter 2016). Gaseous fuels are divided into oil, industrial and natural gas. According to the state, the gas is divided into LPG, Compressed Natural Gas (CNG) and LNG (Žaglinskis et al. 2018). However, according to McGill et al., (2013), other fuels which are not included for practical, economic, or safety-related limitations of ships are as follows: nuclear fuels (Thorium, Uranium, Plutonium, $\mathrm{H}_{3}$ ), wind or solar power (sails, kites, wind turbines, photovoltaic cells), solid boiler fuels (coal, coke, peat, lignite), gas turbine or spark ignition engine-specific fuels (kerosene, ethanol, gasoline), gasification fuels (wood and other cellulosic biomass, sludge and other organic wastes) and electrochemical fuels (hydrogen, batteries). 
In this paper, among all the possible above-mentioned alternative solutions, LNG propulsion, MDO, and scrubber technology are considered and discussed in detail as the best transition solutions.

\section{Liquefied natural gas (LNG)}

LNG is one of the options seen as an alternative fuel for deep sea, short sea and inland navigation ships (Aronietis et al. 2015). Among the technologies that are currently evaluated, the possibility for ships of switching to LNG as a main fuel has raised significant concerns during the last few years (Chen et al. 2018).

Natural gas reduces local air pollutants compared to traditional maritime fuels. LNG in marine transportation is likely to be incentivized where economics favoring natural gas are coupled with air emissions public policy targets (Thomson et al. 2015). Moreover, gaseous fuel available for marine use is natural gas which is not only very low in Sulphur content but it also combusts lower $\mathrm{NO}_{x}, \mathrm{PM}$, and $\mathrm{CO}_{2}$ (McGill et al. 2013). The general characteristics of LNG propulsion are very important to consider this option as a sustainable or transit solution for emission reduction. In the following part, some of the main positive and negative features of LNG propulsion are summarized according to different sources.

It can be observed from Table 3 that different advantages and disadvantages mentioned for LNG are not the same for all the papers and it depends on the research conducted by each author. Regarding the advantages of LNG, reduction of pollutants such as $\mathrm{SO}_{\mathrm{x}}, \mathrm{NO}_{\mathrm{x}}$, and $\mathrm{PM}$ is the most significant factor mentioned by the majority of the authors. Then, cost competitiveness with distillate and residual fuels and energy density are the second and third important features respectively. However, the negative aspects of LNG propulsion are categorized firstly as the problem with compatibility with existing engines which increases the operational and retrofit costs and requirements of more space and weight. Following that, methane slip from engines burning gas and limited bunkering infrastructure are other important disadvantages of LNG propulsion considered by most authors.

However, if vessel owners are to switch to LNG, ports must provide the necessary LNG bunker infrastructure. Port authorities, for their part, can only invest meaningfully in such facilities if they have a rough idea of potential demand for LNG bunker from deep sea, shortsea and inland navigation, as LNG is increasingly substituted for HFO and/or MGO. Moreover, an important aspect in the choice for the use of LNG or lowSulphur fuel are the current day bunker strategies of the shipping companies (Aronietis et al. 2017).

\section{Marine Diesel oil (MDO)}

According to van Rynbach et al., (2018), the simplest option for meeting the upcoming low-Sulphur limits is to burn MGO with Sulphur content at or below $0.1 \%$ in the ECA zones or $0.5 \%$ worldwide starting in 2020 . Moreover, they state that this solution has no effect on the $\mathrm{NO}_{\mathrm{x}}$ emissions and would require some additional technology to reduce $\mathrm{NO}_{\mathrm{x}}$ for ships that have to meet Tier III levels. A negative aspect of MGO is the higher price compared to other fuels (Semolinos et al. 2013; Granskog 2015). There have been some difficulties in existing ships with the change over from heated 


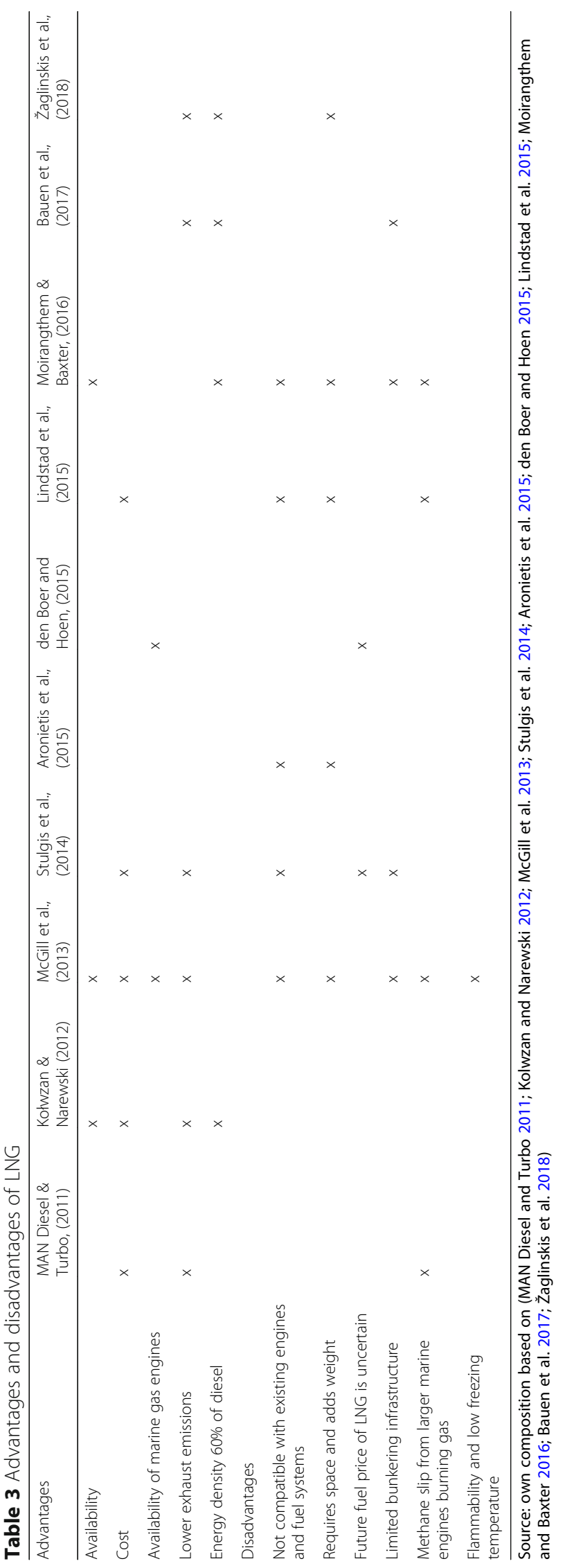


HFO to cool MDO when entering or leaving ECA zones. Semolinos et al., (2013) state that, the level of investment needed is much lower than for LNG and the feasibility, therefore, is higher.

\section{Exhaust gas treatment systems}

Another option to lower emissions and comply with regulations within ECA zones is by installing "scrubber" technology. Scrubbers allow ships in the ECA's to continue to burn traditional bunker fuel, yet still benefit from the savings created by the price difference between (cheaper) traditional bunker fuel and the low-Sulphur diesel that would be required without scrubber technology (Stulgis et al. 2014; Lahtinen 2016). In table 4, the advantages and disadvantages of scrubber technology are provided according to different sources such as McGill et al. 2013; Chryssakis et al. 2014; Stulgis et al. 2014; Aronietis et al. 2015; den Boer and Hoen 2015; van Rynbach et al. 2018. According to table 4, reduction of pollution is the main advantage mentioned by majority of the authors. However, increasing fuel consumption or power consumption is the main disadvantage of using scrubber technology. Since MGO is more expensive than HFO, scrubbers have received attention over the last years and the number of scrubbers installed onboard ships has increased (den Boer and Hoen 2015).

There are four main principles of exhaust gas scrubbing systems: open loop, closed loop, dry and hybrid scrubbers. In Table 5, a brief description of each is reported.

According to Alphaliner (2018), scrubbers are more popular than LNG fuel as an alternative to comply with the new $\mathrm{SO}_{x}$ limits, with only 13 LNG powered units (new builds and conversions) expected ready, while the number of scrubber-fitted container ships (new builds and retrofits) is expected to come close to 200 units by January 2020 when the IMO's global $\mathrm{SO}_{\mathrm{x}}$ limit is reduced to 0.5\%. Despite increased interest from vessel owners for scrubbers and LNG, the total number of such IMO-compliant ships will only be a fraction of the total containership fleet. The vast majority of ships will need to switch to low-Sulphur bunker in 2020. According to Greenport (2019), It is stated that "After members of the Clean Shipping Alliance 2020 Executive Committee presented port officials with scientific evidence concluding that the wastewater generated by the Exhaust Gas Cleaning System (EGCS) process was environmentally acceptable and within regulatory limits, the ports in Europe, the Americas, Asia and Australasia indicated that they do not intend to submit any papers to the IMO pertaining to EGCS operation unless new, compelling research comes to light". In this research, an open loop scrubber system is taken into account.

\section{Economic comparison of alternative technologies}

Based on the literature review, there are some sources which compare different alternative technologies from an economic perspective. In Table 6, the applied approach, cost elements and general conclusions of each paper are reported. The table is based on the author's composition according to different sources namely Man Diesel and Turbo 


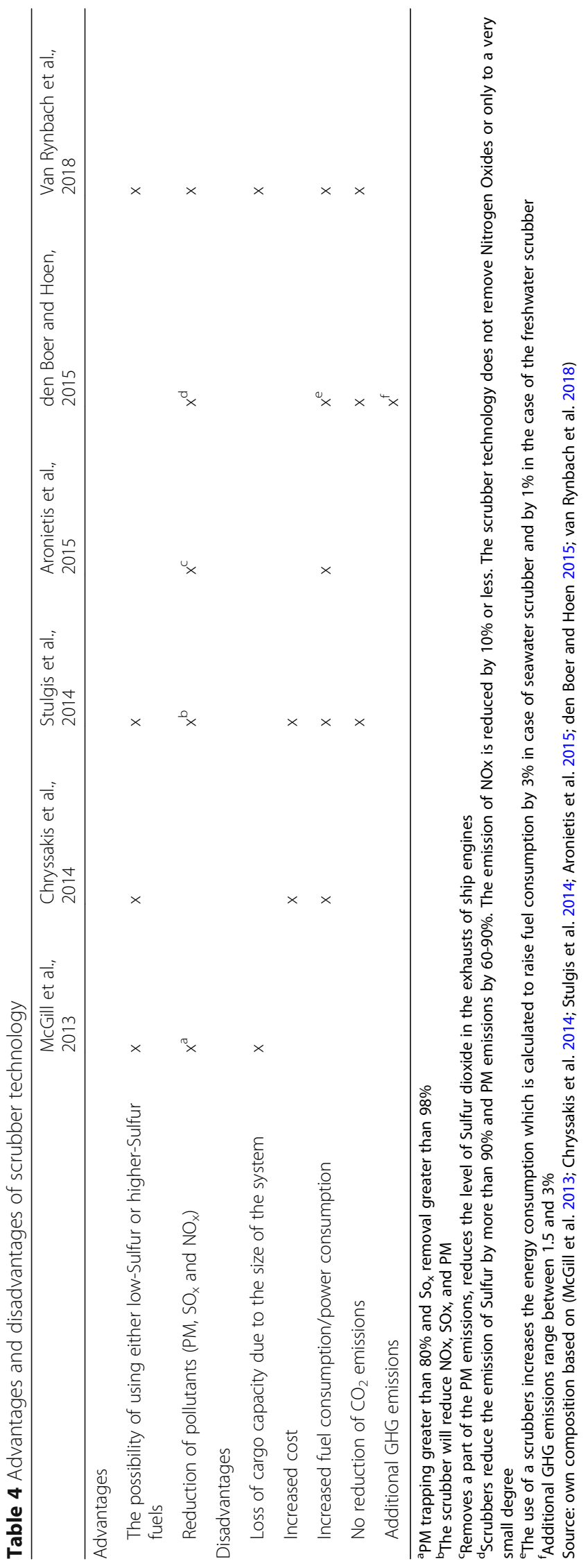


Table 5 Different scrubber systems and relevant features

$\begin{array}{ll}\text { Open loop seawater } & \text { Water and Sulfur react to form Sulfur acid, which is neutralized with alkaline } \\ \text { scrubbers } & \text { components in the sea water. Filters separate particles and oil from the mixture } \\ & \text { before the cleaned water is sent back into the sea. It typically uses seawater as the } \\ & \text { scrubbing medium and requires relatively large space on board. The negative } \\ & \text { characteristic of an open loop system is its greater energy consumption compared to } \\ & \text { a closed loop system, but there is no need for chemical additives like caustic soda in } \\ & \text { a closed loop system. Increase of sulfur in seawater would impact the water quality. } \\ \text { Closed loop scrubbers } & \text { This type uses freshwater with the addition of an alkaline chemical (such as caustic } \\ & \text { soda). Therefore, no wash-water is produced that would have to be pumped into the } \\ & \text { sea. This type requires more space than open loop systems. } \\ & \text { It uses a dry chemical, such as calcium hydroxide and Sulfur is locked in, meaning it } \\ \text { cannot burden the biosphere at sea anymore. It does not use any liquids in the } & \text { process but exhaust gases are cleaned with hydrated lime-treated granulates. Exhaust } \\ & \text { gas flows through granulated limestone. It combines with the Sulfur to form gypsum, } \\ & \text { which can then be disposed of on land. The storage room has to be created on } \\ \text { board for granulate, which reduces cargo capacity. An advantage of a dry scrubber is } & \text { its lower energy consumption compared to a wet scrubber. } \\ \text { It gives the possibility to either use a closed loop or open loop technology. Hybrid } \\ \text { scrubbers are generally used as an open loop system when the vessel is operating in } \\ \text { the open sea and as a closed loop system when operating in harbor or estuaries, } \\ \text { where water discharge is prohibited. }\end{array}$

Source: Own composition based on (McGill et al. 2013; Aronietis et al. 2014; den Boer and Hoen 2015; Lahtinen 2016)

2011; Aronietis et al. 2014; Hsu et al. 2014; DNV GL and MAN Diesel and Turbo 2016; Fearnleys 2017; Abadie et al. 2017.

The above studies display the comparison of different alternative technologies from a ship-owner perspective. They compare the LNG propulsion by scrubber technology or other available options for specific ship types and maritime routes which are beneficial for vessel owners. The missing part of previous studies is that none of them considers the economic impact of the new technologies on the chain cost hence, from the shipper point of view.

In this research, the objectives are not only economic comparison of three different alternative fuel options from a vessel owner point of view but also an economic assessment of different options from a shipper perspective, which shows how alternative options will affect the generalized chain cost and which option provides the lowest generalized chain cost. The latter assessment provides input to the policymaking process and provides a great view for logistics operators in order to deploy the best alternative solutions.

\section{Methodology}

The starting point for the analysis is the Chain Cost Model, proposed by van Hassel et al., (van Hassel et al. 2016a, 2016b). For the purpose of this paper, the model has been further developed and adapted in order to deal with the specific research questions addressed in this paper. Section 3.1 provides a brief overview of the model and its components. Section 3.2 deals with the necessary input parameters. Subsequently, section 3.3 looks at some of the adaptations to the base model.

\section{Overview of the base model}

The purpose of the base Chain Cost Model is to calculate the generalized chain cost per TEU from a selected point of origin in the hinterland, via a predefined container 
Table 6 Researches on alternative technologies

\begin{tabular}{|c|c|c|c|c|c|c|}
\hline Source & $\begin{array}{l}\text { Man Diesel } \\
\text { and Turbo }\end{array}$ & Aronietis et al., & Hsu et al., & $\begin{array}{l}\text { DNV GL and } \\
\text { MAN Diesel \& } \\
\text { Turbo }\end{array}$ & Fearnleys & Abadie at al., \\
\hline Year & 2011 & 2014 & 2014 & 2016 & 2017 & 2017 \\
\hline $\begin{array}{l}\text { Research } \\
\text { question(s) - } \\
\text { Objective(s) }\end{array}$ & $\begin{array}{l}\text { Are exhaust } \\
\text { gas treatment } \\
\text { systems the } \\
\text { preferred } \\
\text { technical } \\
\text { solution? }\end{array}$ & $\begin{array}{l}\text { Selection of } \\
\text { the best } \\
\text { retrofit } \\
\text { solutions. }\end{array}$ & $\begin{array}{l}\text { Assessment of } \\
\text { possible } \\
\text { alternative } \\
\text { solutions such } \\
\text { as MGO, LNG, } \\
\text { scrubber } \\
\text { system, } \\
\text { Methanol (Me } \\
\text { OH). }\end{array}$ & $\begin{array}{l}\text { Analyzing the } \\
\text { costs and } \\
\text { benefits of } \\
\text { various fuel } \\
\text { options for a } \\
\text { case with one } \\
\text { particular ship } \\
\text { and its } \\
\text { operating } \\
\text { pattern. }\end{array}$ & $\begin{array}{l}\text { Comparison of } \\
\text { different } \\
\text { alternative } \\
\text { shipping fuels. }\end{array}$ & $\begin{array}{l}\text { Adaptation of } \\
\text { the shipping } \\
\text { sector to } \\
\text { stricter } \\
\text { emissions } \\
\text { regulations by } \\
\text { either fuel } \\
\text { switching or } \\
\text { installing a } \\
\text { scrubber. }\end{array}$ \\
\hline $\begin{array}{l}\text { Approach - } \\
\text { methodology } \\
\text { applied }\end{array}$ & $\begin{array}{l}\text { Reference } \\
\text { vessel uses } \\
\text { MGO inside } \\
\text { ECA-zones by } \\
2015 \text { or within } \\
\text { EU ports. } \\
\text { Outside ECA- } \\
\text { zones, HFO is } \\
\text { used and a } \\
\text { Low-Sulfur } \\
\text { Heavy Oil } \\
\text { (LSHO) with a } \\
0.5 \% \text { Sulfur } \\
\text { content by } \\
2020 \text {. }\end{array}$ & $\begin{array}{l}\text { An aggregate } \\
\text { simulation } \\
\text { model that } \\
\text { simulates the } \\
\text { impacts retrofit } \\
\text { solutions } \\
\text { would have if } \\
\text { they were } \\
\text { implemented } \\
\text { in the market. }\end{array}$ & $\begin{array}{l}\text { Life-cycle cost } \\
\text { analysis, which } \\
\text { includes } \\
\text { different stages } \\
\text { such as } \\
\text { planning, } \\
\text { design, } \\
\text { construction, } \\
\text { operation, and } \\
\text { end of life. }\end{array}$ & $\begin{array}{l}\text { Two different } \\
\text { scenarios of } \\
\text { fuel prices: a } \\
\text { high price } \\
\text { scenario based } \\
\text { on the fuel } \\
\text { prices in mid- } \\
2014 \text {, and a } \\
\text { low price } \\
\text { scenario based } \\
\text { on fuel prices } \\
\text { in mid-2015. }\end{array}$ & $\begin{array}{l}\text { Four different } \\
\text { scenarios for } \\
\text { container } \\
\text { ships: } \\
\text { LNG new-built, } \\
\text { MGO, Scrubber } \\
\text { and LNG } \\
\text { conversion. }\end{array}$ & $\begin{array}{l}\text { Stochastic } \\
\text { modeling to } \\
\text { deal with } \\
\text { uncertainties } \\
\text { concerning the } \\
\text { price of the } \\
\text { different fuels. }\end{array}$ \\
\hline Cost elements & $\begin{array}{l}\text { Relevant costs } \\
\text { for key } \\
\text { technologies. }\end{array}$ & / & $\begin{array}{l}\text { Capital cost, } \\
\text { installation } \\
\text { cost, operation } \\
\text { cost, } \\
\text { maintenance } \\
\text { cost, and total } \\
\text { life-cycle cost. }\end{array}$ & $\begin{array}{l}\text { Additional } \\
\text { investment } \\
\text { and operating } \\
\text { costs } \\
\text { compared to a } \\
\text { standard fuel } \\
\text { variant using } \\
\text { HFO outside of } \\
\text { SECA and } \\
\text { MGO inside. }\end{array}$ & $\begin{array}{l}\text { Capital } \\
\text { expenses } \\
\text { (CAPEX) and } \\
\text { voyage } \\
\text { expenses } \\
\text { (VOYEX). }\end{array}$ & $\begin{array}{l}\text { How many } \\
\text { tons of fuel are } \\
\text { used under } \\
\text { each scenario } \\
\text { of time at sea } \\
\text { using } \\
\text { scrubbers and } \\
\text { switching fuels } \\
\text { for both types } \\
\text { of fuel and two } \\
\text { points in time: } \\
\text { in the initial } \\
\text { period (up to } \\
\text { the end of } \\
\text { 2019) and in } \\
\text { the second } \\
\text { period (2020 } \\
\text { and beyond). }\end{array}$ \\
\hline Perspective & / & / & $\begin{array}{l}\text { Three key } \\
\text { elements are } \\
\text { environmental, } \\
\text { economic and } \\
\text { technical issues } \\
\text { during each } \\
\text { stage of the } \\
\text { analysis. } \\
\text { The model is } \\
\text { applied for a } \\
\text { duration of } 15 \\
\text { years (from } \\
2013 \text { till 2028) } \\
\text { by estimation } \\
\text { of fuel prices } \\
\text { by considering } \\
\text { an escalation } \\
\text { rate of 5\%. }\end{array}$ & $\begin{array}{l}\text { Alternative } \\
\text { fuels selected } \\
\text { were LNG, LPG, } \\
\text { methanol and } \\
\text { new ultra-low- } \\
\text { Sulfur fuel oil, a } \\
\text { so-called } \\
\text { hybrid fuel. }\end{array}$ & / & $\begin{array}{l}\text { Focus is solely } \\
\text { on the options } \\
\text { available to the } \\
\text { existing fleet } \\
\text { and therefore } \\
\text { considering } \\
\text { only the } \\
\text { options of } \\
\text { switching to } \\
\text { low-Sulfur } \\
\text { marine fuels } \\
\text { and installing a } \\
\text { scrubber. } \\
\text { The paper does } \\
\text { not set out } \\
\text { mainly to } \\
\text { analyze carbon } \\
\text { emissions from } \\
\text { shipping and } \\
\text { slow steaming } \\
\text { and reducing } \\
\text { the speed of } \\
\text { vessels is not } \\
\text { considered. }\end{array}$ \\
\hline
\end{tabular}


Table 6 Researches on alternative technologies (Continued)

\begin{tabular}{|c|c|c|c|c|c|c|}
\hline Ships & $\begin{array}{l}\text { 2,500 TEU, } 4, \\
600 \text { TEU, } 8,500 \\
\text { TEU, } 14,000 \\
\text { TEU, and } 18 \text {, } \\
000 \text { TEU }\end{array}$ & $\begin{array}{l}\text { Ro-Ro and Ro- } \\
\text { Pax ships }\end{array}$ & $\begin{array}{l}\text { Ro-Pax (1300 } \\
\text { passengers and } \\
300 \text { cars). } \\
\text { Cruise vessel } \\
\text { (3080 } \\
\text { passengers). } \\
\text { Container } \\
\text { feeder (1700 } \\
\text { TEU). } \\
\text { Small ferry (600 } \\
\text { passengers and } \\
160 \text { cars). }\end{array}$ & $\begin{array}{l}\text { LR1 product } \\
\text { tanker }\end{array}$ & $\begin{array}{l}\text { 8,500 TEU } \\
\text { container ship }\end{array}$ & / \\
\hline Routes & $\begin{array}{l}\text { Round trips for } \\
\text { three trades: } \\
\text { intra-European, } \\
\text { Europe-Latin } \\
\text { America and } \\
\text { Europe-Asia. }\end{array}$ & / & / & $\begin{array}{l}\text { The route } \\
\text { between } \\
\text { Northern } \\
\text { America and } \\
\text { Northern } \\
\text { Europe: } \\
\text { Houston- } \\
\text { Rotterdam; } \\
\text { Ventspils- } \\
\text { Houston. }\end{array}$ & $\begin{array}{l}\text { Rotterdam to } \\
\text { Shanghai - } \\
\text { Shanghai to } \\
\text { Rotterdam }\end{array}$ & / \\
\hline $\begin{array}{l}\text { Conclusion - } \\
\text { results }\end{array}$ & $\begin{array}{l}\text { Use of } L N G \text { as } \\
\text { a ship fuel } \\
\text { promises a } \\
\text { lower emission } \\
\text { level and, } \\
\text { given the right } \\
\text { circumstances, } \\
\text { lower fuel } \\
\text { costs. } \\
\text { Three main } \\
\text { parameters: } \\
\text { investment } \\
\text { costs for LNG } \\
\text { tank system, } \\
\text { the price } \\
\text { difference } \\
\text { between LNG } \\
\text { and HFO, and } \\
\text { share of } \\
\text { operation } \\
\text { inside ECA's. }\end{array}$ & $\begin{array}{l}\text { Speed } \\
\text { reduction } \\
\text { brings the } \\
\text { most benefits. } \\
\text { Scrubbers } \\
\text { perform well } \\
\text { economically, } \\
\text { but the } \\
\text { emission and } \\
\text { energy } \\
\text { performance } \\
\text { are worse than } \\
\text { those of the } \\
\text { other } \\
\text { technologies. } \\
\text { Bad economic } \\
\text { performance } \\
\text { for dual-fuel. }\end{array}$ & $\begin{array}{l}\text { The fuel price } \\
\text { has a } \\
\text { significant } \\
\text { impact. } \\
\text { LNG \& } \\
\text { scrubber are } \\
\text { better for a } \\
\text { long life cycle } \\
\text { and methanol } \\
\text { is better for a } \\
\text { short life cycle. }\end{array}$ & $\begin{array}{l}\text { The high price } \\
\text { scenario } \\
\text { resulted in the } \\
\text { highest annual } \\
\text { cost difference } \\
\text { for the } \\
\text { alternatives as } \\
\text { well as the } \\
\text { shortest } \\
\text { payback times. } \\
\text { Methanol and } \\
\text { ultra-low-Sulfur } \\
\text { fuel oil do not } \\
\text { show financial } \\
\text { feasibility. LNG } \\
\text { and LPG are } \\
\text { both financially } \\
\text { interesting } \\
\text { alternative } \\
\text { fuels, and LPG } \\
\text { was found to } \\
\text { be at least as } \\
\text { good as LNG, } \\
\text { used both } \\
\text { inside and } \\
\text { outside SECA } \\
\text { regions. }\end{array}$ & $\begin{array}{l}\text { Scrubbers have } \\
\text { the lowest } \\
\text { cost, then LNG } \\
\text { for new-built } \\
\text { ships is on the } \\
\text { second, and } \\
\text { MGO and LNG } \\
\text { conversion } \\
\text { ships are } \\
\text { located on the } \\
\text { third and } \\
\text { fourth places } \\
\text { respectively. } \\
\text { For existing } \\
\text { vessels, LNG } \\
\text { and scrubbers } \\
\text { provide a very } \\
\text { sound option. }\end{array}$ & $\begin{array}{l}\text { The choice of } \\
\text { one option or } \\
\text { the other } \\
\text { depends on } \\
\text { various factors } \\
\text { such as the } \\
\text { price of fuels, } \\
\text { the area in } \\
\text { which the ship } \\
\text { usually } \\
\text { operates, the } \\
\text { regulations } \\
\text { applicable to it, } \\
\text { the number of } \\
\text { days at sea and } \\
\text { the remaining } \\
\text { useful lifetime } \\
\text { of the ship. } \\
\text { The longer the } \\
\text { remaining } \\
\text { lifetime of the } \\
\text { vessel is, the } \\
\text { longer the } \\
\text { vessels spend } \\
\text { in ECAs and } \\
\text { the longer they } \\
\text { spend at sea, } \\
\text { the option of } \\
\text { investing in } \\
\text { scrubbers } \\
\text { becomes more } \\
\text { attractive. }\end{array}$ \\
\hline
\end{tabular}

Source: own composition based on (Man Diesel and Turbo 2011; Aronietis et al. 2014; Hsu et al. 2014; DNV GL and MAN Diesel and Turbo 2016; Fearnleys 2017; Abadie et al. 2017)

loop, to a destination point in another hinterland. The container loop encompasses the maritime leg of the supply chain. Fig. 2 provides a general overview of the original model (van Hassel et al. 2016a, 2016b).

In the Chain Cost Model, different aggregated hinterlands are connected via a route along with ports (bold lines in Fig. 2). The aggregated hinterlands are defined as a summation of different smaller geographical areas, which in Europe correspond to NUTS-2 areas. Each aggregated hinterland is served by at least one and usually by several ports. Each port is built up of a set of terminals, all of which have their own set of characteristics. From each port terminal, the hinterland connections via road, rail, and inland 


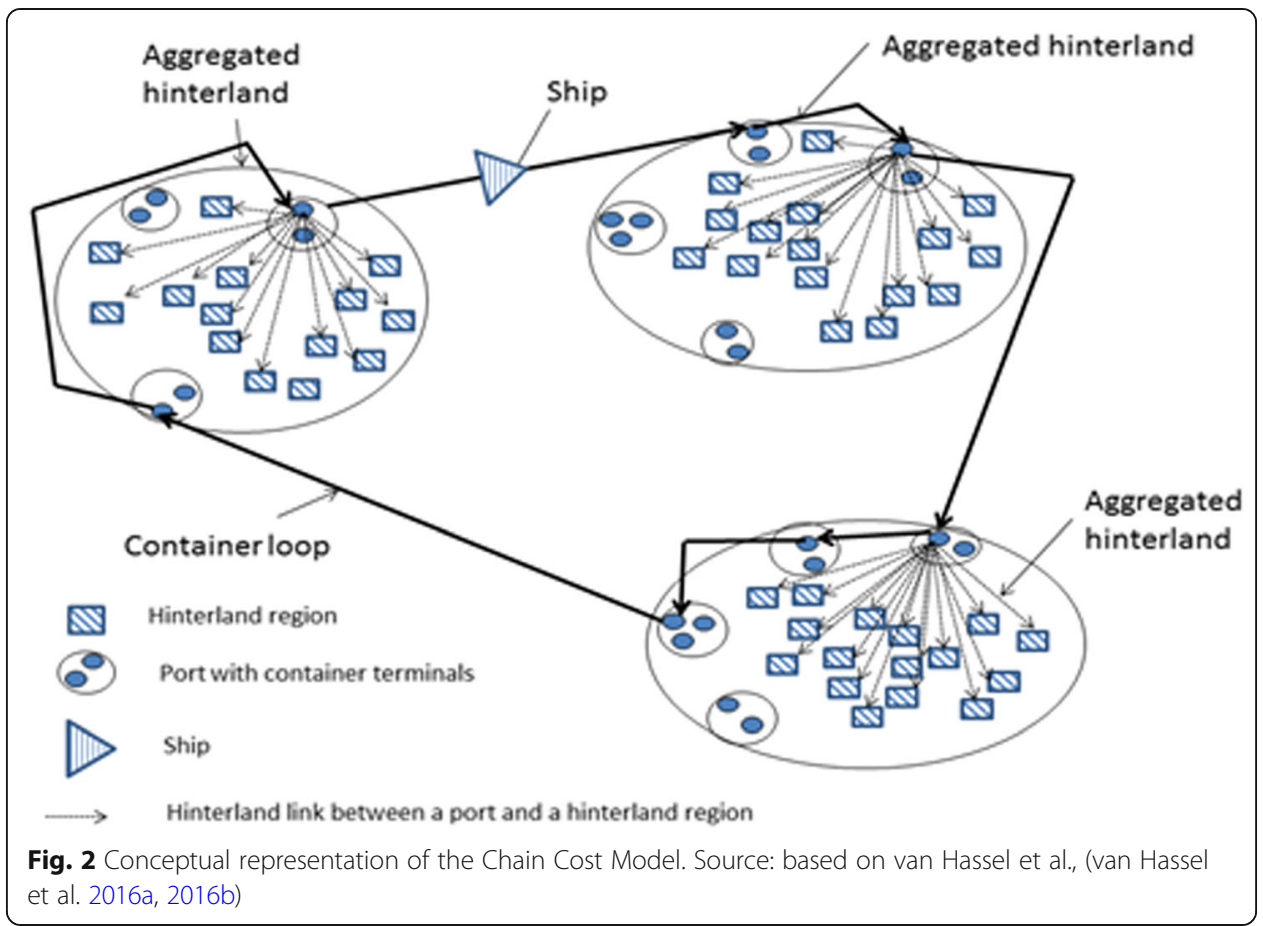

waterways (if applicable) to all the disaggregated hinterland regions are incorporated into the model. (van Hassel et al. 2016a, 2016b).

In the model, a logistics chain is defined as a route from a specific hinterland region $(i)$ to another hinterland region $(j)$. A chain, therefore, has a beginning and an end. The aggregated hinterland in which the origin of the chain is situated is called the aggregated from-hinterland $(\mathrm{Y})$, whereas the hinterland where the end of the chain is located is referred to as the aggregated to-hinterland (Z) (van Hassel et al. 2016a, 2016b).

\section{Input parameters}

The input for the Chain Cost Model consists of three main elements. The first input is the selection of a container loop. An actual loop can be incorporated in the model using data obtained from the websites of the concerned container lines. In the Chain Cost Model, it is possible to build a container loop for which a database of 70 different ports can be used. Secondly, a specific vessel needs to be selected to sail the specific loop. The main standard input parameters related to the ship are a sailing speed of 22 knots and capacity utilization of $80 \%$. The capacity utilization of inland vessels and trains is assumed to be $80 \%$. All other input parameters are taken from port and terminal websites and other sources such as Drewry (2015) for the terminal throughputs. For a more detailed description of the model, reference is made to van Hassel et al., (van Hassel et al. 2016a, 2016b).

\section{Adjustments to the base model}

The focus of this article is on the economic evaluation of three different methods to comply with the standards of the ECA zones. This analysis will be done for both the 
chain cost and for the vessel owner cost. Therefore, given the specific objective of the present paper, the base model needs to be adjusted.

Firstly, the model has been extended with functionality to allow calculating the vessel owner cost. This means that the total cost for operating a container vessel, on a given loop, can be calculated. These costs include all the vessel-related cost such as running cost, voyage cost (including the cost in ports) and fixed cost. All these costs are calculated for a total round trip.

Secondly, more maritime distance data is collected from MarineTraffic (2018) containing the distance sailed in ECA zones. This means that for each port-to-port combination, in the total maritime distance database in the model, this additional information is added. The maritime distance database is a 80 by 80 matrix. Furthermore, in the model, 20 different container vessel sizes are included, ranging from 500 TEU load capacity up to 20,000 TEU. The vessel data is collected from RINA (1992- 2016).

Based on this information, the fuel cost can be calculated when a vessel is sailing in ECA zones using either MDO, LNG or HFO (including a scrubber).

The time that a vessel is sailing in ECA zones is determined by the speed of the vessel and by the distance sailing in the ECA zones. The fuel consumption of the vessel, using different measures to mitigate the ECA regulations is then determined by the following formula.

$$
F C_{\text {Voyage }, i}=F C_{E C A, i}+F C_{N O N E C A, i}
$$

In which $\mathrm{FC}_{\text {Voyage, } \mathrm{i}}$ is the fuel cost for a voyage for vessel type $i$, while $\mathrm{FC}_{\mathrm{ECA}, \mathrm{i}}$ and $\mathrm{FC}_{\mathrm{NONECA}, \mathrm{i}}$ are the fuel costs for a voyage in either ECA zones or non-ECA zones.

$$
F C_{E C A, i}=\frac{D_{E C A}}{V_{\text {Vessel }, i}} \cdot S F C_{i, j} \cdot \frac{\left(\Delta_{\text {Payload }}+\Delta_{L W, i}\right)^{2 / 3} \cdot V_{\text {Vessel }, i}{ }^{3}}{C_{\text {admin }, \mathrm{i}} \cdot P b_{i}} \cdot F P_{j}
$$

With:

$D_{E C A}=$ the distance sailed in the ECA zones $(\mathrm{nm})$.

$V_{\text {Vessel, } i}=$ the speed of vessel type $\mathrm{i}$.

$S F C_{i, j}=$ the specific fuel consumption of the considered engine type or installation $j$ (LNG, MDO or scrubbers) for vessel type i (tonnes/h).

The deltas represent the displacement of the vessel, both for the payload and for the lightweight and are both expressed in cubic meters.

$P b_{i}=$ the installed engine power in $\mathrm{kW}$.

$C_{\text {Admin, } i}=$ the admiralty constant of vessel type $\mathrm{i}\left(\mathrm{kW} /\left(\mathrm{kn}^{3} \cdot\right.\right.$ tonne $\left.^{2 / 3)}\right)$.

Including these elements in the model allows researching the effects of operational speed changes.

$F P_{j}=$ the fuel price per ton for fuel type $\mathrm{j}$ (HFO, MDO or LNG). For $F C_{N O N E C A, i}$, a similar equation is used only when the distance $D_{\text {nonECA }}$ is used, which is the distance sailed on a specific trip between two ports which are not in the ECA zones (nautical mile).

By adding the above-mentioned formula, the model needs some data to be able to quantify the fuel consumption. In order to calculate the fuel consumption of each vessel type, the following graph is used to consider the fuel consumption of HFO, LNG, and MGO. 
Table 7 Specific fuel oil consumption

\begin{tabular}{ll}
\hline Specific fuel oil consumption (typical for $52 \mathrm{MW}$ engine) & \\
\hline Type of fuel & Fuel consumption $(\mathrm{kg} / \mathrm{KWh})$ \\
\hline HFO & 0.18 \\
MGO & 0.18 \\
LNG & 0.13 \\
Pilot fuel & 0.02 \\
\hline
\end{tabular}

Source: Own composition based on MAN Diesel and Turbo (2011)

Based on Table 7, the fuel consumption for LNG engines is determined as $0.15 \mathrm{~kg} /$ $\mathrm{kWh}$. The LNG engine fuel consumption includes not only the direct fuel consumption of LNG $(0.13 \mathrm{~kg} / \mathrm{kWh})$ but also the fuel consumption of the pilot fuel $(0.02 \mathrm{~kg} / \mathrm{kWh})$. Moreover, for HFO and MDO, fuel consumption is equal to $0.18 \mathrm{~kg} / \mathrm{kWh}$.

Based on the installed power, along with the design speed of the vessel, fuel consumption per hour can be determined. Fuel consumption per hour (tons/hour) is obtained by multiplying fuel consumption for each fuel $(\mathrm{kg} / \mathrm{kWh})$ by the Installed power of the vessel type $(\mathrm{kW} / 1000)$. This calculation is reported in Table 8 for each fuel used and each size of the vessel.

The design speed of the vessel and the needed power to sail at that speed (85\% MCR) are taken from the data of RINA (1992- 2016) for the different vessel types.

For the fuel consumption of vessels sailing on MDO and HFO, the hourly fuel consumption at design speed is taken from RINA (1992- 2016) for the different container vessels. An overview of the different fuel consumptions for container vessels ranging from 4600 TEU to 18,800 TEU is reported in Table 8.

Next to the adjustments to the fuel cost, also some cost impacts are expected in the running cost of the container vessels. These running costs include crew cost, repair cost, maintenance cost and insurance cost, which are given in van Hassel et al., (van Hassel et al. 2016a, 2016b). According to Man diesel and Turbo (2011), by using LNG as fuel, crew cost, maintenance, and repair cost increase by $10 \%$ compared to using MDO or HFO. While, by applying the scrubber scenario, crew cost, maintenance, and repair cost will rise by $20 \%$. Besides running cost, external costs of pollutants such as

Table 8 Fuel consumption of vessels for different fuels and scrubber technology

\begin{tabular}{|c|c|c|c|c|c|c|}
\hline \multirow[t]{2}{*}{$\begin{array}{l}\text { Vessel } \\
\text { Size } \\
\text { (TEU) }\end{array}$} & \multirow[t]{2}{*}{$\begin{array}{l}\text { Installed } \\
\text { Power } \\
\text { (kw) }\end{array}$} & $\begin{array}{l}\text { Fuel } \\
\text { Consumption } \\
\text { main engine } \\
\text { (tons/hour) }\end{array}$ & \multirow[t]{2}{*}{$\begin{array}{l}\text { Fuel } \\
\text { Consumption } \\
\text { auxiliary engine } \\
\text { (tons/hour) }\end{array}$} & \multirow{2}{*}{$\begin{array}{l}\text { Fuel } \\
\text { Consumption } \\
\text { main engine } \\
\text { (tons/hour) } \\
\text { LNG }\end{array}$} & $\begin{array}{l}\text { Fuel } \\
\text { Consumption } \\
\text { main engine } \\
\text { (tons/hour) }\end{array}$ & $\begin{array}{l}\text { Fuel } \\
\text { Consumption } \\
\text { auxiliary engine } \\
\text { (tons/hour) }\end{array}$ \\
\hline & & $\mathrm{HFO} / \mathrm{MDO}$ & & & \multicolumn{2}{|c|}{ Scrubber system Scenario ${ }^{a}$} \\
\hline 4600 & 36,560 & 6.58 & 0.30 & 5.48 & 6.78 & 0.31 \\
\hline 5466 & 24,680 & 4.44 & 0.31 & 3.70 & 4.58 & 0.32 \\
\hline 9115 & 41,400 & 7.45 & 0.73 & 6.21 & 7.68 & 0.75 \\
\hline 13,892 & 62,030 & 11.17 & 0.53 & 9.30 & 11.50 & 0.55 \\
\hline 18,800 & 61,000 & 10.98 & 0.57 & 9.15 & 11.31 & 0.59 \\
\hline
\end{tabular}

${ }^{\mathrm{a}}$ In the model, a $3 \%$ increase in fuel consumption is considered for the scrubber system: the use of a scrubber increases the energy consumption which is calculated to raise fuel consumption by $3 \%$ in case of seawater scrubber (open loop) and by $1 \%$ in case of freshwater scrubber (closed loop) (den Boer \& Hoen, 2015). Therefore, for fuel consumption of main/auxiliary engine of scrubber (tons/hour), the following equation is used: [(fuel consumption of main/auxiliary of $\mathrm{HFO})+($ fuel consumption of main/auxiliary of HFO * (3\%))]

Source: Own composition based on RINA (1992- 2016) and MAN Diesel and Turbo (2011) 
Table 9 External costs of pollutants

\begin{tabular}{ll}
\hline Type of cost & Value (Euro/Ton) \\
\hline Cost $\mathrm{SO}_{x}$ & 0.04 \\
Cost NOx & 1328 \\
Cost PM10 & 0.48 \\
Cost $\mathrm{CO}_{2}$ & 25 \\
\hline
\end{tabular}

Source: van Essen et al., (van Essen et al. 2011)

$\mathrm{SO}_{\mathrm{x}}, \mathrm{NO}_{\mathrm{x}}, \mathrm{CO}_{2}$, and PM are considered in the calculation. The external costs are taken from van Essen et al., (van Essen et al. 2011) and the value for $\mathrm{SO}_{\mathrm{x}}$ is $0.04 \mathrm{EUR} / \mathrm{ton}$, for $\mathrm{NO}_{\mathrm{x}}$, it is $1328 \mathrm{EUR} /$ ton, for PM10, it is $0.48 \mathrm{EUR} /$ ton and for $\mathrm{CO}_{2}$, it is $25 \mathrm{EUR} / \mathrm{ton}$. Table 9 reports the external costs of pollutants.

The last cost element that requires some additional inputs is the capital cost. Starting from van Hassel et al., (van Hassel et al. 2016a, 2016b), here, the cost must also include the investment of LNG propulsion (retrofit) or a scrubber system. According to Aronietis et al., (2015), the investment cost for LNG propulsion and scrubber system are reported in Table 10.

The average investment cost varies based on the ship type and vessel size. The lifetime of the LNG system is 27 years, while for the scrubber system, it is considered 10 years (Aronietis et al., (2015)). Moreover, the yearly investment cost for LNG propulsion is obtained by dividing the average investment cost by the total lifetime (27 years), while for scrubber technology, the average investment cost is divided by 10 years to acquire the yearly investment cost.

\section{Scenario development}

To compare selected alternative technologies, different scenarios are developed. Firstly, there is the reference scenario. This scenario equals the "business as usual" situation with the aim of providing a comparison reference for the modeled alternative scenarios. In the reference scenario, the vessel complies to the ECA regulation by using MDO fuel, while outside the ECA zones, the vessel will use HFO.

The alternative scenarios tested are explained in Table 11. Every scenario is a combination of input data that characterizes the investigated technology. These include associated investment cost and fuel cost impacts. The two alternative scenarios tested in this research are the LNG scenario and the scrubber system scenario. The main differences of the scenarios depend on the types of engine and fuel used inside and outside

Table 10 Investment cost for LNG propulsion and scrubber system of ship types

\begin{tabular}{lllllll}
\hline $\begin{array}{l}\text { Vessel } \\
\text { Size } \\
\text { [TEU] }\end{array}$ & $\begin{array}{l}\text { Average investment } \\
\text { cost [Euro] }\end{array}$ & $\begin{array}{l}\text { Lifetime } \\
\text { [Year] }\end{array}$ & $\begin{array}{l}\text { Investment cost } \\
\text { [Euro per year] }\end{array}$ & $\begin{array}{l}\text { Average } \\
\text { investment cost } \\
\text { [Euro] } \\
\text { Scrubber system }\end{array}$ & $\begin{array}{l}\text { Lifetime } \\
\text { [Year] }\end{array}$ & $\begin{array}{l}\text { Investment cost } \\
\text { [Euro per year] }\end{array}$ \\
\hline 4600 & $15,000,000$ & 27 & 555,556 & $2,500,000$ & 10 & 250,000 \\
5466 & $15,000,000$ & 27 & 555,556 & $2,500,000$ & 10 & 250,000 \\
9115 & $17,000,000$ & 27 & 629,630 & $2,500,000$ & 10 & 250,000 \\
13,892 & $19,000,000$ & 27 & 703,704 & $3,000,000$ & 10 & 300,000 \\
18,800 & $20,000,000$ & 27 & 740,741 & $3,000,000$ & 10 & 300,000 \\
\hline
\end{tabular}

Source: Own composition based on Aronietis et al., (2015) 
Table 11 Different scenarios based on the type of engine

\begin{tabular}{llll}
\hline Scenario & Engine & Fuel used inside ECA's & Fuel used outside ECA's \\
\hline Reference Scenario & Diesel Engine & Marine Diesel Oil (MDO) & Heavy Fuel Oil (HFO) \\
LNG Scenario & LNG Engine & LNG & LNG \\
Scrubber system & Diesel Engine & Heavy Fuel Oil (HFO) with scrubber & Heavy Fuel Oil (HFO) \\
\hline
\end{tabular}

ECA zones. Table 11 presents the different scenarios considered in this research. In the first column, the reference and the alternative scenarios are mentioned. In the second column, the type of engine for each scenario is pointed out. In the third and fourth columns, the fuel used inside and outside ECA zones is stated respectively.

In this research, different scenarios are applied to two different routes. The first route is the trade lane from Far East Asia to Europe, while the second route focuses on the US to Europe, hence the Transatlantic route. For each route, different container vessel sizes are tested. An overview is given in Table 12.

Besides the different vessel sizes, also different vessel speeds are analyzed. This means that, for each size of the vessel, three different speeds (\% of design speed of the vessel size $(90 \%, 80 \%$, and $70 \%))$ are considered, hence resulting in 27 scenarios for each maritime route.

Data with respect to the fuel cost is collected from Bunkerworld (2018). An average fuel cost of $400 \mathrm{EUR} /$ ton for HFO, $494 \mathrm{EUR} /$ ton for MDO and $310 \mathrm{EUR} / \mathrm{ton}$ for LNG is assumed. For the model convenience, all the values are expressed or converted in EURO. Furthermore, in order to assess the impact of the considered options from a maritime supply chain point of view, firstly, a maritime supply chain must be determined. The considered supply chains in the scenarios are given in Table 13.

\section{Scenario analysis and empirical results}

The adjusted chain cost model is applied to the above-mentioned scenarios. For each scenario, the cost from a vessel owner and the chain point of view are calculated. Firstly, the results of the maritime cost for the Asia - Europe route are discussed, followed by the results for the container loop from the US to Europe.

\section{Asia to Europe route}

Each researched route is divided into two sub-sections. In the first sub-section, the results of the vessel owner costs are given, while in the second sub-section, the results for the supply chain impact are reported.

Table 12 Ports in the loop of each route ${ }^{a}$

\begin{tabular}{lll}
\hline Loop & Ports in the loop & $\begin{array}{l}\text { Vessel } \\
\text { sizes }\end{array}$ \\
\hline Asia- & $\begin{array}{l}\text { Ningbo - Shanghai - Xiamen - Hong Kong - Yantian - Port Kelang - Tanger Med - } \\
\text { Europe }\end{array}$ & $\begin{array}{l}\text { Southampton - Hamburg - Bremerhafen - Zeebrugge - Rotterdam - Le Havre - } \\
13,892 \text { TEU }\end{array}$ \\
& Marsaxlokk - Khor al Fakkan - Jebel Ali - Ningbo & 18,800 TEU \\
US- & Miami - Jacksonville - Savannah - Charleston - New York - Antwerpen - Bremerhafen & 4600 TEU \\
Europe & - Rotterdam - Le Havre - New York - Norfolk - Charleston - Miami & 5466 TEU \\
& & 9115 TEU
\end{tabular}

${ }^{\text {aThese routes are based on existing container loops }}$ 
Table 13 Considered supply chains

\begin{tabular}{lll}
\hline Route & Origin & Destination \\
\hline Asia - EU & Shanghai & Brussels \\
& Shanghai & Munich \\
& Shanghai & Berlin \\
US - EU & Jacksonville & Brussels \\
& Jacksonville & Munich \\
& Jacksonville & Berlin \\
\hline
\end{tabular}

\section{Vessel owner cost}

For Asia to Europe loop, the cost differential for the two alternative scenarios compared to the reference scenario is given. For each scenario, the different vessel types are considered as well as the three different speeds. The results are given in Fig. 3.

Figure 3 shows that for the Asia - EU loop, the most economical alternative technology would be the LNG system since it features the highest cost savings with respect to other scenarios. However, for vessels of 18,800 TEU, the maritime cost increases significantly, which leads to the reduction of cost savings with respect to the other two vessel types.

It should be mentioned that for all the three scenarios and together by speed reduction, the maritime cost decreases as well. The latter means that the cost savings increase. The reason is that speed reduction leads to a decrease in fuel consumption, consequently resulting in a reduction of the maritime cost.

Furthermore, for the same scenarios and variation of speeds, the calculations are repeated by changing the fuel price of MDO and LNG. The aim is to figure out how the maritime and chain costs are affected by changing the price of fuel. To do so, the fuel cost of $\mathrm{MDO}$ is decreased to 425 (Euro/ton) which is a $13 \%$ reduction compared to base fuel price, while, the fuel cost of LNG is increased by $18 \%$ and reaches 380 (Euro/ ton). All the other parameters are kept as the first part of the methodology and the model is run to recalculate the maritime and chain costs for the two maritime routes and for all sizes of vessels. Figure 4 depicts the cost savings of alternative solutions with respect to the reference scenario.

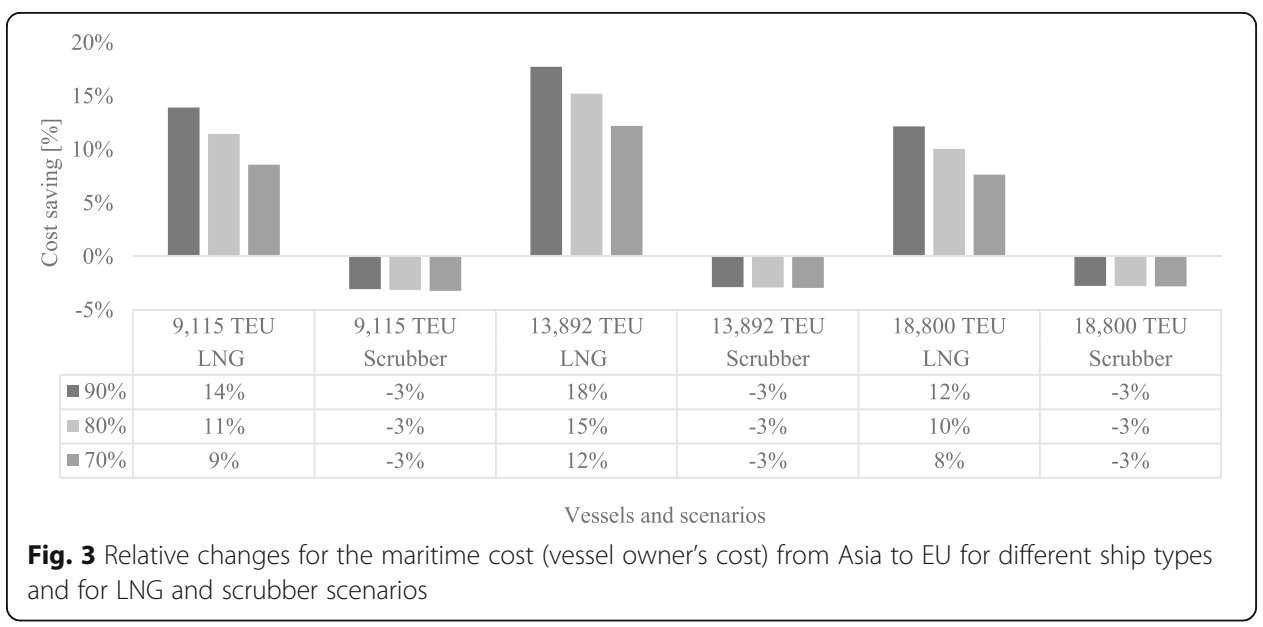


By changing the fuel price of LNG and MDO and comparing Figs. 3 and 4, some new results are achieved. On the Asia - Europe route, comparing three scenarios shows that for both the reference and scrubber scenarios, the maritime cost decreases gradually with respect to the base fuel price situation (cost savings remain almost the same), while in the LNG scenario, this cost increases, which shows the decrease in cost savings. Similar to the base fuel price situation, the LNG system remains the cheapest and the cost saving of this system is higher than under the scrubber scenario. It should be noticed that the fuel price does affect the maritime cost significantly, and by increasing the fuel price of LNG, the cost savings is reduced compared to the base fuel price situation.

As the size of the vessel increases, the maritime cost enhances correspondingly, however, since, for the vessel of 18,800 TEU, the design speed and the installed power of the propulsion parameter are lower than vessel of 13,892 TEU, therefore, the maritime cost for this vessel is smaller (because fuel consumption is derived from installed power and if it is lower, it does affect the maritime cost).

\section{Supply chain cost impact}

The generalized chain cost for each of the mentioned ports in section 4 is reported in Fig. 5.

By comparing the generalized chain cost obtained for each destination, it can be observed that the cost saving depends on the distance to the port. On the route from Shanghai to Brussels (the lowest generalized chain cost is obtained via the port of Zeebruges), most of the cost is made up of maritime cost, because the hinterland cost is relatively low, which states that the largest cost saving is for Brussels compared to the other cities. However, by transporting the cargo from Shanghai to Munich (the lowest generalized chain cost is obtained via the port of Bremerhaven) or Berlin (the lowest generalized chain cost is obtained via the port of Hamburg), the hinterland distances are longer; and consequently, the hinterland cost in larger. Therefore, the maritime cost contribution to the overall cost mainly depends on the hinterland distance.

Moreover, comparing the cost savings of the LNG scenario at $90 \%$ of the speed (Figs. 3 and 5) shows that the effect of using alternative fuel technology is higher for the vessel owner than for the cargo owner. For example, the cost savings for the vessel owner

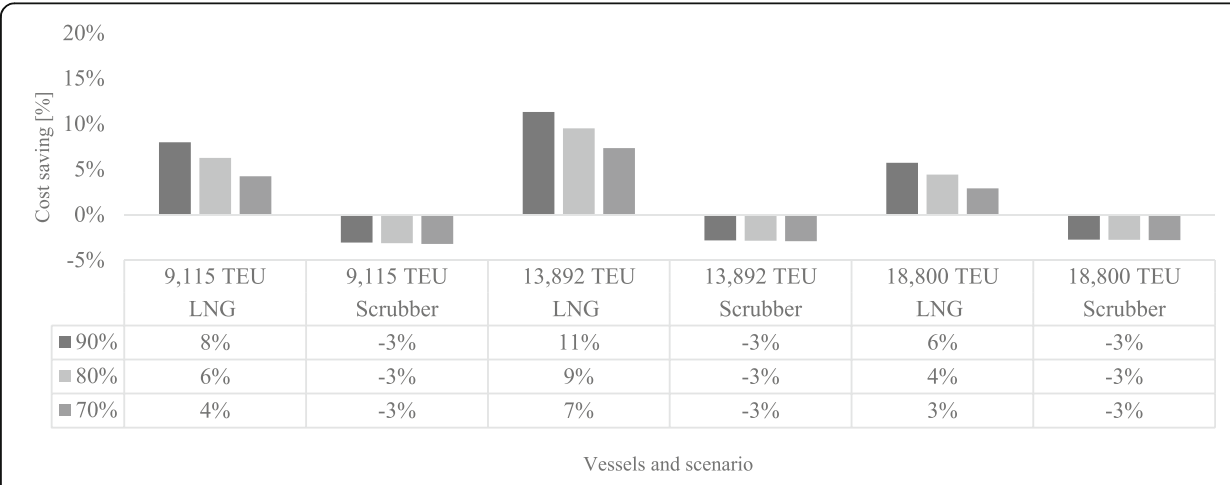

Fig. 4 Relative changes for the maritime cost (vessel owner's cost) from Asia to EU for different ship types and for $L N G$ and scrubber scenarios (by increasing the price of LNG and decreasing the price of MDO) 


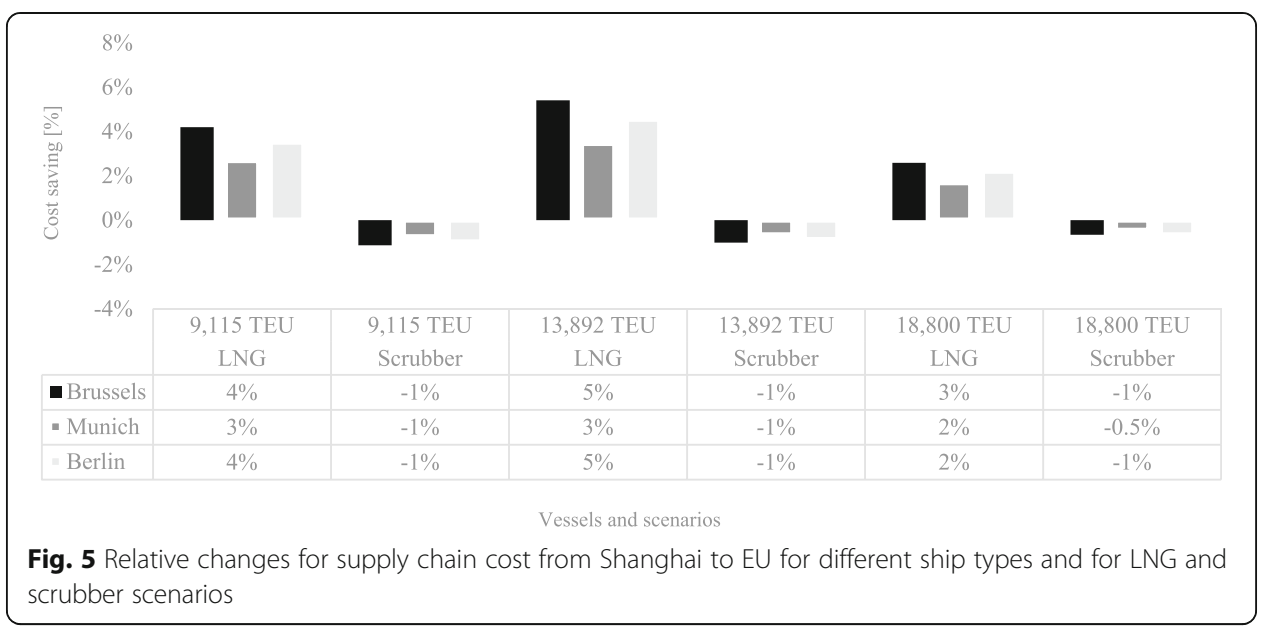

deploying a ship of 9115 TEU equals 14\%, while this impact from a chain cost perspective reduces to $4 \%$. In the case of a 13,892 TEU ship, the cost savings drop from $18 \%$ to approximately $5 \%$. In other words, the impacts are relatively high for cost savings from the vessel owner point of view for LNG propulsion, but from a supply chain perspective, this effect is lower. The results of the alternative fuel costs are given in Fig. 6.

By comparing Figs. 5 and 6, it can be observed that the fuel price affects the generalized cost as well. Since the LNG cost increases, the generalized cost grows as well and it leads to the reduction of cost savings of LNG compared to the base fuel price situation. However, for the scrubber technology, the cost savings remain approximately unchanged compared to the base fuel price (a small change in cost saving). For both base and alternative fuel prices, the LNG propulsion leads to higher cost savings and reflects the better economic option compared to scrubber technology. Even so, this ratio is not significant and is about $5 \%$ at the maximum level for ship type 13,892 TEU.

\section{US to Europe route}

In parallel, the vessel owner cost and the generalized chain cost are calculated for the trade lane US-Europe.

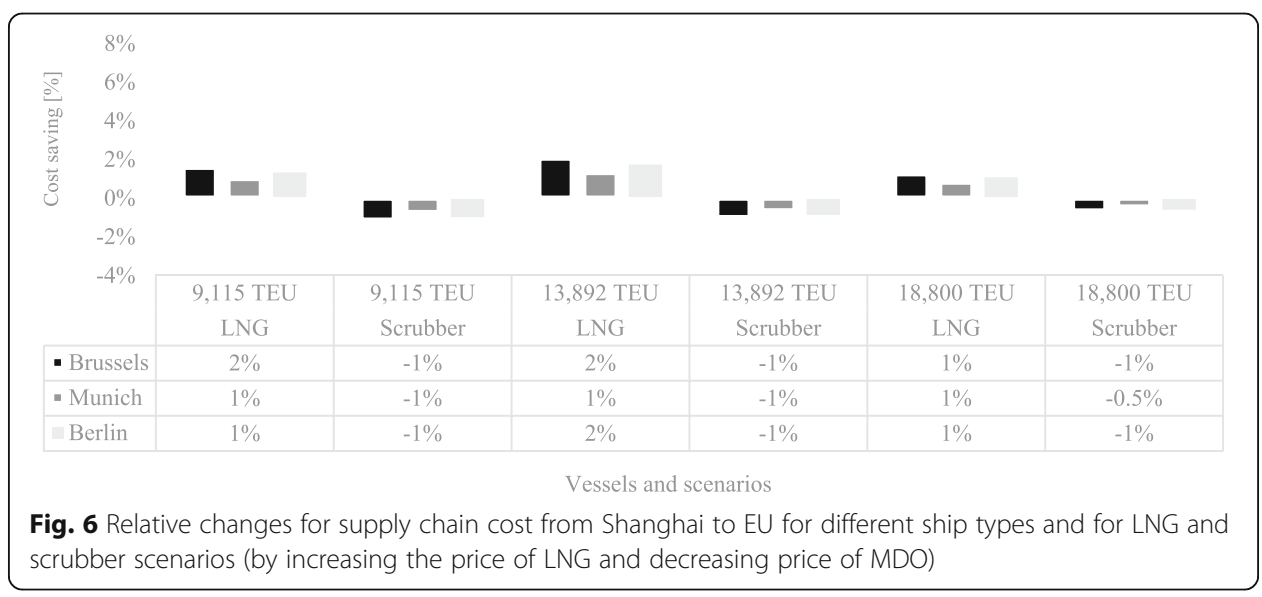




\section{Vessel owner cost}

The cost savings of different technologies are reported in Fig. 7.

According to the above table, for all the vessels, there are positive cost savings of LNG propulsion, which states the lowest maritime cost compared to the other options. Next, the scrubber system is the most expensive option, however, this value is not significant, by representing only $4 \%$ cost increment compared to the reference scenario.

By increasing the size of the vessel, the maritime cost raises as well, however, since, for the vessel of 5466 TEU, the installed power of the propulsion parameter and design speed are smaller than for a vessel of 4,600 TEU, therefore, the maritime cost for this vessel is lower than for the other two (because fuel consumption is derived from installed power and if it is lower, it does affect the maritime cost). In Fig. 8, the results of the alternative fuel costs scenarios are given.

On this route, by comparing Figs. 7 and 8, the findings for the US - Europe route are as follows. The maritime cost reduces gradually for both the reference and scrubber scenarios. However, for the LNG system, the maritime cost increases for all the vessel sizes, which leads to the reduction of the cost savings of the LNG system with respect to the base fuel price situation. For example, for the ship type of 4600 TEU and for $90 \%$ of speed, the cost savings diminish from $22 \%$ to $13 \%$, by changing the price of LNG. This fact is valid for ship types 5466 TEU and 9115 TEU by decreasing the cost saving from $12 \%$ to $8 \%$ and from $19 \%$ to $10 \%$ respectively. Therefore, it can be concluded that, by changing the fuel price, LNG becomes a less economic option but still has the highest cost savings compared to the scrubber system and is considered the cheapest fuel alternative.

In addition, the cost savings of the scrubber scenario is negative for all the vessels, which means that it is a more expensive option with respect to LNG scenarios. Moreover, by increasing the fuel price of MDO, the effect is not significant by comparing scrubber technology by the reference situation, which shows the same amount of cost savings with respect to base fuel price.

\section{Supply chain cost}

With respect to the generalized chain cost, the results of the analysis are presented in Fig. 9.

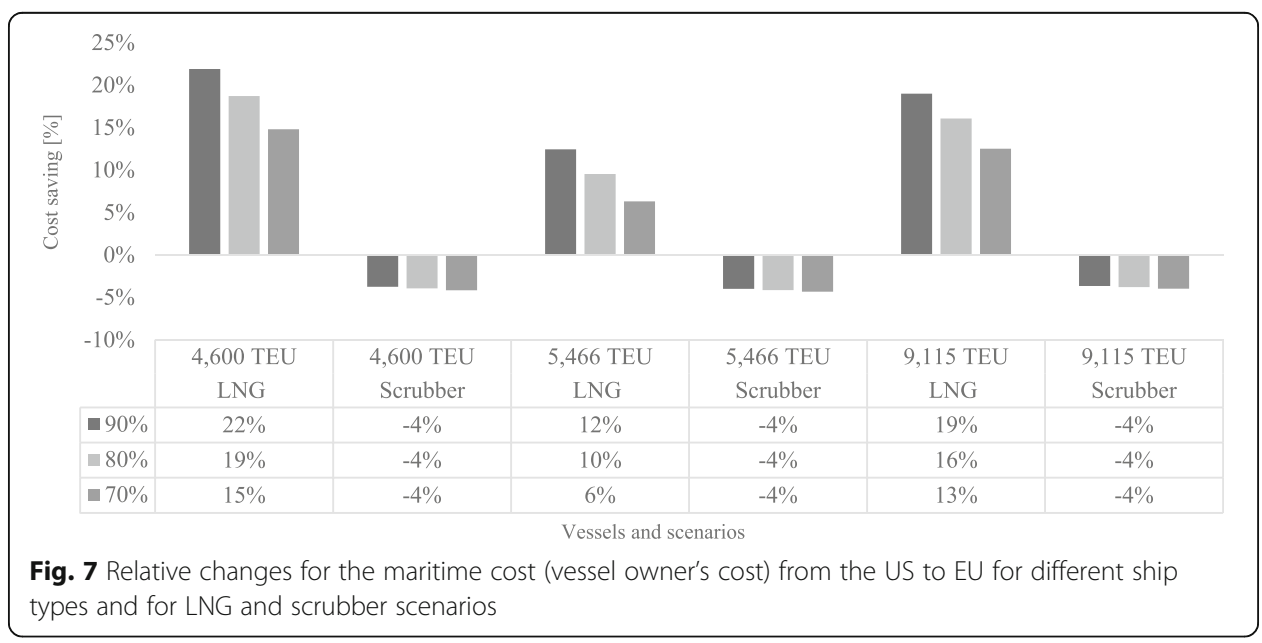




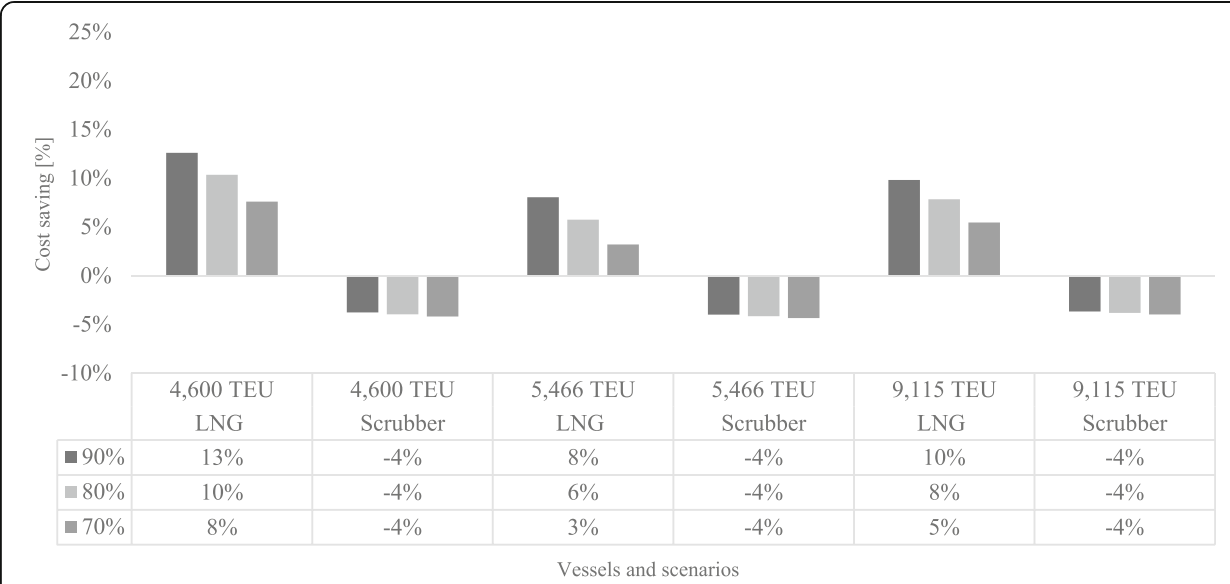

Fig. 8 Relative changes for the maritime cost (vessel owner's cost) from the US to EU for different ship types and for $L N G$ and scrubber scenarios (by increasing the price of LNG and decreasing the price of $\mathrm{MDO}$ )

On the route from Jacksonville to Europe, the lowest generalized cost is obtained via the port of Antwerp for final destination Brussels, while for the trip from Jacksonville to Munich or Berlin, the lowest generalized cost is incurred via the port of Bremerhaven. Figure 10 gives the results of the supply chain cost for alternative fuel costs.

By comparing Fig. 9 and Fig. 10, the effect of the fuel price on the supply chain cost is displayed. By increasing the fuel price of LNG, the cost savings of this alternative option decrease compared to the base fuel cost situation. However, the cost savings of the scrubber system remain unchanged. By increasing the fuel price of LNG, although the cost savings of this option reduce, however, it is still a better economic option by presenting the lowest generalized cost.

By comparing the obtained cost savings from Figs. 7 and 9, it is observed that the impact of the cost is higher for the vessel owner rather than for the supply chain perspective for LNG propulsion. For a vessel of 4600 TEU and 90\% of speed, this value drops from $22 \%$ to around $5 \%$. For a vessel of 5466 TEU, the cost savings for the ship-owner

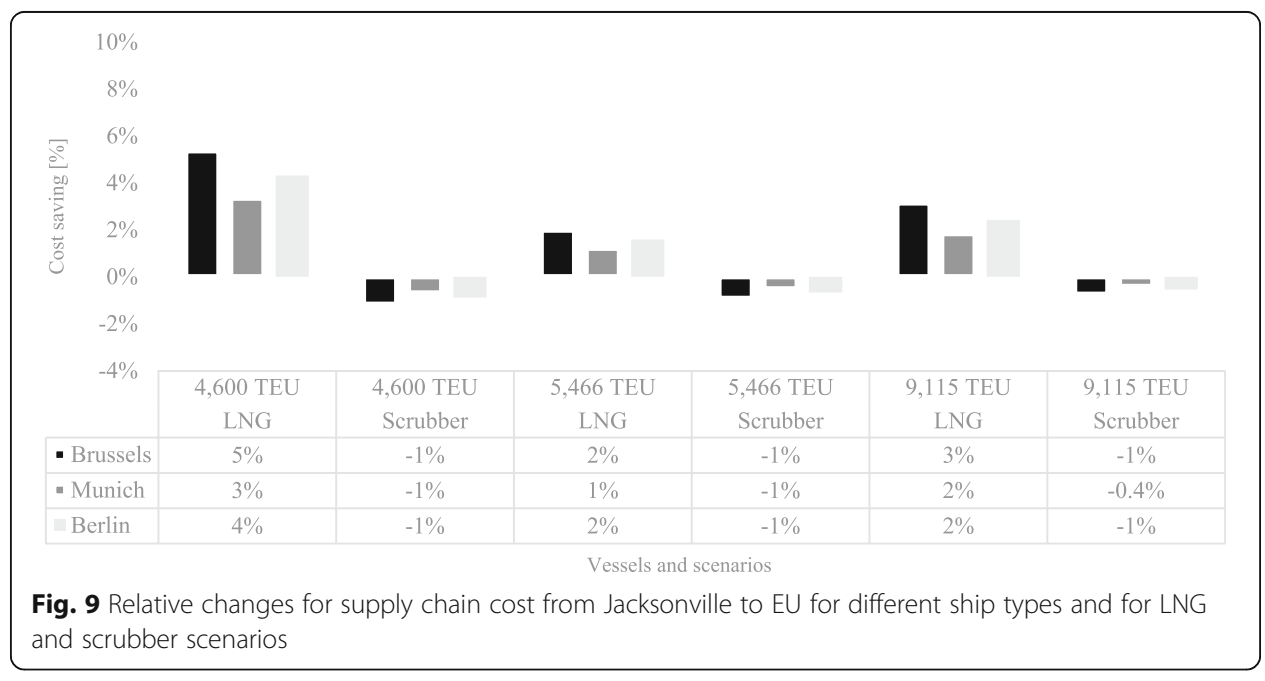




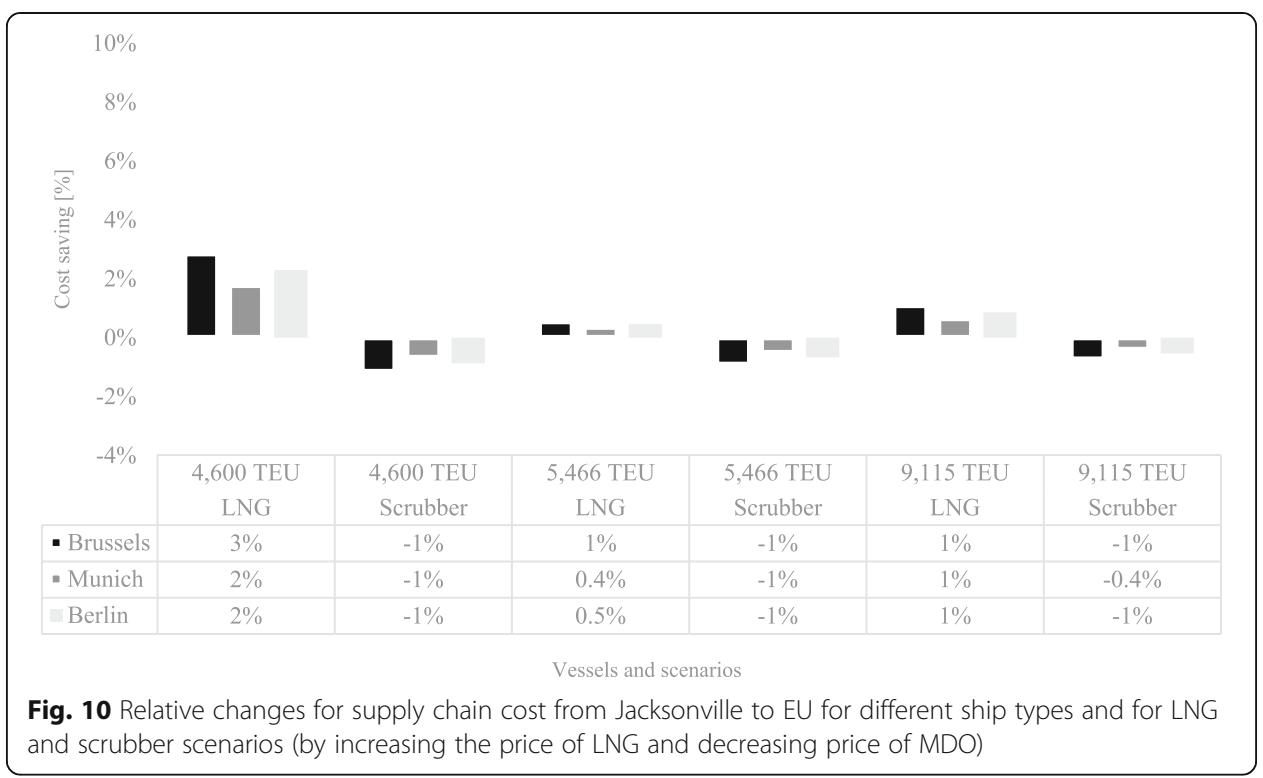

are $12 \%$, while the cost savings from a supply chain perspective is only $2 \%$. For a vessel of 9115 TEU, the cost savings reduce from $19 \%$ to $3 \%$, which is a significant value.

\section{Conclusion}

International maritime shipping is confronted from 2006 onwards and will face new regulation until 2030 by different policy actors (i.e. IMO, the EU) in order to reduce the volume of pollutants emitted from vessels globally and in ECA zones in a more strict way. In order to respect the legislation, there are some alternative options for vessel owners, such as LNG propulsion, MDO, and scrubber technology. In this research, the mentioned alternative solutions are assessed economically not only form a vessel owner point of view but more importantly, from a shipper perspective by evaluating the generalized chain cost. The latter assessment shows how alternative options will affect the generalized chain cost and which option will provide the lowest generalized chain cost, which affects the policymaking process and provides a great view for logistics operators in order to deploy the best alternative solutions.

From a theoretical perspective, this research develops a new approach of the economic evaluation of using alternative technologies by assessing the generalized chain cost. By doing so, not only the impact on the vessel owner is assessed, but also the perspective of the shipper is taken into account, which is novel. According to the literature review accomplished in this research, LNG is seen as an alternative solution to be used in maritime shipping. LNG is considered one of the promising solutions which shows better economic evaluation and has lower level of emission. The second-best option is scrubber technology. The findings of this study confirm that LNG can be considered an alternative and possible solution to replace HFO in maritime shipping as it shows the lowest maritime cost compared to the other alternative technologies (also for different HFO - LNG spreads).

This research has two research objectives; first, the evaluation of the cost for the vessel owner and second, the assessment of chain cost of some types of containerships for three alternative fuel options, being LNG, MDO and scrubber technology. For this purpose, a 
chain cost model is used and adapted. The obtained results for different fuel technologies are compared to each other in order to figure out which option would be the best from an economic point of view. The fuel alternative technologies such as LNG propulsion and scrubber system have been compared economically to a reference case using MDO within the ECA zones and for some types of ship, trading between Europe, the US, and China. The economic comparison is made with three different scenarios of engine types and the fuel used inside and outside the ECA zones. Moreover, this comparison has been put forward by using two different levels of fuel prices by increasing the fuel price of LNG by 70 [euro/ton] and decreasing the price of MDO by 80 [euro/ton] to realize the effect of fuel price on the maritime and chain costs. In this model, the external costs of pollutants such as $\mathrm{SO}_{\mathrm{x}}, \mathrm{NO}_{\mathrm{x}}, \mathrm{CO}_{2}$, and $\mathrm{PM}$ are taken into consideration.

Based on the performed analysis, firstly, it was found that the LNG system has the lowest maritime cost compared to the reference and scrubber scenarios for both Asia and the US to EU routes. Secondly, the cost savings of the LNG scenario are higher than for the scrubber scenario with respect to the reference scenario, while the cost savings of the scrubber scenario are negative for all the vessels for both vessel owner maritime cost and supply chain cost. The results show that for both Asia-EU and USEU routes, LNG propulsion is the most economical option by demonstrating the lowest vessel owner cost and generalized chain cost compared to the scrubber technology and reference scenario. In addition, by comparing the maritime cost of the vessels for all three scenarios and both routes, it is observed that as the percentage of design speed is decreasing, the cost of maritime transport decreases as well. Besides, the maritime cost increases as the size of the vessel increases.

By analyzing the obtained results, it can be derived that the supply chain impact depends not only on ship size but more significantly on the maritime distance. It can be interpreted that, in a longer maritime distance from Asia to Europe, the maritime cost is relatively higher compared to the shorter maritime distance from the US to Europe and in this case, the majority of costs are related to hinterland costs.

By performing sensitivity analysis and increasing the LNG price and decreasing the MDO price, it is observed that the LNG system remains the most economical alternative solution, however, the cost savings reduce significantly compared to base fuel price. The reason is that the maritime cost of LNG increases significantly by increasing the fuel price of LNG and at the same time, the maritime cost of the reference scenario decreases by diminishing the fuel price of MDO, which leads to the reduction of the cost savings of LNG propulsion. Moreover, the cost savings of the scrubber scenario with respect to the reference scenario do change slowly.

Therefore, it can be concluded that by changing the fuel price, the LNG scenario becomes a less economic option but still has the highest cost savings compared to the scrubber system and is considered the most economical fuel alternative. By comparing the alternative fuel costs with base fuel price situation, it is found that the maritime cost is influenced by the price of fuel in which for LNG propulsion this influence is much higher and more significant. Moreover, the effect of using alternative fuel technology is higher for the vessel owner rather than the cargo owner. In other words, the impacts are relatively high for the cost saving from the vessel owner point of view for LNG propulsion, but from the supply chain perspective, this effect is lower. This fact reveals that the price of fuel plays an important role in order to choose an alternative 
fuel option, besides features such as installation cost, crew cost, and maintenance cost, that are other significant factors.

The obtained results are relevant for both logistics operators (shipping companies, shippers, freight forwarders, etc.) and policymakers. For logistics operators, the findings are relevant, as they allow making the economically most rewarding investments, taking into account potential internalization of external costs. For governments, it is important to know which solution gives the best socio-economic cost returns.

The scope of this study was limited in terms of the choice of ship types and investment cost. Firstly, only containerized vessels are taken into account. Secondly, the average investment cost for LNG propulsion and scrubber systems varies based on the ship type and vessel size. In this research, the average investment cost is considered according to the literature which means that by increasing the size of the vessel, this average cost in increased accordingly; however, in reality, the exact investment cost of each vessel size might be different.

In order to extend the research objectives regarding this topic, further research might be done by including other types of vessels such as bulk carriers, Ro-Ro vessels and etc., taking into account the reduction of other pollutants such as $\mathrm{CO}_{2}$ for further analysis. Moreover, other maritime routes might be considered such as South America to Europe.

\section{Acknowledgements}

We like to thank the green shipping project for the financial support for the development of this research.

\section{Authors' contributions}

SAM performed the literature review, performed the analysis and wrote the first draft of the paper. EvH adapted the initial model so that the specific research questions of this paper could be addressed. He also wrote the method section of the paper and supervised SAM during the development of the paper. TV and CS also supervised SAM during the development of the paper and contributed by improving the quality of the paper with various meetings. All authors read and approved the final manuscript.

Funding

The development of this research was financed with the support of the Green shipping: Governance \& Innovation for a sustainable Maritime Supply chain project. Grant number 895-2017-1003.

\section{Availability of data and materials}

The data used in this paper was collected via desk research and via models that were already available at the department of transport and regional economics.

\section{Competing interests}

The authors declare that they have no competing interests.

Received: 7 June 2019 Accepted: 30 October 2019

Published online: 30 December 2019

\section{References}

Abadie LM, Goicoechea N, Galarraga I (2017) Adapting the shipping sector to stricter emissions regulations: fuel switching or installing a scrubber? Transp Res Part D: Transp Environ 57:237-250

Alphaliner (2018) The Worldwide Reference in Liner Shipping. https://www.alphaliner.com/. Accessed 10 Sep 2019

Aronietis R, Frouws K, Meersman H, Sys C, Van de Voorde E, Vanelslander T (2015) In: Altosole M, Francescutto A (eds) Retrofit: from selection of technologies to regulatory framework. 18th International Conference on Ships and Shipping Research 2015, Lecco, June 24th-26th/, pp 657-670

Aronietis R, Sys C, van Hassel E, Vanelslander T (2017) Investigating the bunkering choice determinants: the case of the port of Antwerp. J shipp trd 2:8. https://doi.org/10.1186/s41072-017-0025-7

Aronietis R, Sys C, Vanelslander T (2014) Ship retrofit solutions: economic, energy and environmental impacts. Conference on maritime-port technology (MTEC), Trondheim, pp 57-66

Bauen A, Gomez I, OudeNijeweme D, Paraschiv M (2017) Alternative fuels expert group report. European Commission

Bunkerworld (2018) Bunkerworld Index (BWI). http://www.bunkerworld.com/prices/bunkerworldindex/. Accessed 10 Sep 2019

Chen S, Zheng S, Zhang Q (2018) Investment decisions under uncertainty on LNG-powered vessels for environmental compliance. J shipp trd 3:5. https://doi.org/10.1186/s41072-018-0031-4

Chryssakis C, Balland O, Tvete HA, Brandsæter A (2014) Alternative fuels for shipping. DNV GL

den Boer LC, Hoen M (2015) Scrubbers: an economic and ecological assessment. CE Delft 
Drewry (2015) Maritime Research - Ship Operating Costs Annual Review and Forecast 2017/18. https://www.drewry.co.uk/ maritime-research/maritime-research. Accessed 10 Sep 2019

Fearnleys (2017) Competing on Price: Making LNG as a Bunker Fuel Commercially Viable

GARD (2018) Chinese ECAs - Sulphur requirements for marine fuels. http://www.gard.no/web/updates/content/21736671/ gard-alert-chinese-ecas-sulphur-requirements-for-marine-fuels. Accessed 10 Sep 2019

DNV GL, MAN Diesel \& Turbo (2016) Costs and benefits of alternative fuels for an LR1 product tanker. DNV GL and MAN Diesel \& Turbo

Granskog C (2015) Economic feasibility of different solutions for complying with MARPOL Sulphur emission directive

Greenport (2019) GreenPort | Balancing Environmental Challenges with Economic Demands. https://www.greenport.com/. Accessed 10 Sep 2019

Hsu P-C, Bronsart R, Göckes T (2014) A life cycle cost analysis of using alternative technologies on short sea shipping vessels in ECAs

IMO (2011) Mandatory energy efficiency measures for international shipping adopted at IMO environment meeting Retrieved 2011

IPCC (2013) IPCC fifth assessment report. IPCC, Geneva

Kolbia (2019) Korea LNG Bunkering Industry Association. http://www.kolbia.org/en/contents/sub02_04.php. Accessed 10 Sep 2019

Kolwzan K, Narewski M (2012) Alternative fuels for marine applications. Latvian Journal of Chemistry, p 398

Lahtinen JM (2016) Closed-loop exhaust gas scrubber onboard a merchant ship: technical, economical, environmental and operational viewpoints. Vaasan yliopisto

Lindstad H, Sandaas I, Strømman AH (2015) Assessment of cost as a function of abatement options in maritime emission control areas. Transp Res Part D: Transp Environ 38:41-48. https://doi.org/10.1016/j.trd.2015.04.018

MAN Diesel \& Turbo (2011) Costs and Benefits of LNG as Ship Fuel for Container Vessels

MarineTraffic (2018) MarineTraffic: Global Ship Tracking Intelligence | AIS Marine Traffic. Https://www.marinetraffic.com/nl/ voyage-planner/. Accessed 10 Sep 2019

McGill R, Remley W, Winther K (2013) Alternative fuels for marine applications - a report from the IEA advanced motor fuels implementing agreement

Moirangthem K, Baxter D (2016) Alternative fuels for marine and inland waterways. European Commission JRC Institute for Energy and Transport

Perera LP, Mo B (2016) Emission control based energy efficiency measures in ship operations. Appl Ocean Res 60:29-46. https://doi.org/10.1016/j.apor.2016.08.006

RINA (2016) RINA Events \& Conference 2016. https://www.rina.org.uk/RINA_2016_Events.html. Accessed 10 Sep 2019

Roy B, Comer B (2017) Alternatives to heavy fuel oil use in the Arctic: economic and environmental tradeoffs

Semolinos P, Olsen G, Giacosa A (2013) LNG as marine fuel: challenges to be overvome

Stevens L, Sys C, Vanelslander T, Van Hassel E (2015) Is new emission legislation stimulating the implementation of sustainable and energy-efficient maritime technologies? Res Transp Bus Manag 17:14-25. https://doi.org/10.1016/j.rtbm. 2015.10.003

Stulgis V, Smith T, Rehmatulla N, Powers J, Hoppe J (2014) Hidden treasure: financial models for retrofits. Carbon War Room and UCL Energy Institute

Sys C, Vanelslander T, Adriaenssens M, Van Rillaer I (2015) International emission regulation in sea transport : economic feasibility and impact. https://doi.org/10.1016/J.TRD.2015.06.009

Thomson H, Corbett JJ, Winebrake JJ (2015) Natural gas as a marine fuel. Energy Policy 87:153-167. https://doi.org/10.1016/j. enpol.2015.08.027

Unctad (2011) Review of Maritime Transport 2011 United Nations publication. Sales No. E.11.II.D.4, New York and Geneva

Unctad (2012) Review of Maritime Transport 2012 United Nations publication. Sales No. E.12.II.D.17, New York and Geneva Unctad (2019) Review of maritime transport 2018. United Nations Conference on Trade and Development

van Essen H, Schroten A, Otten M, Sutter D, Schreyer C, Zandonella R, Maibach M, Doll C (2011) External costs of transport in Europe. CE Delft, Netherlands

van Hassel E, Meersman H, Van de Voorde E, Vanelslander T (2016a) Impact of scale increase of container ships on the generalised chain cost. Marit Policy Manag 43:192-208. https://doi.org/10.1080/03088839.2015.1132342

van Hassel E, Meersman H, Van de Voorde E, Vanelslander T (2016b) North-south container port competition in Europe: the effect of changing environmental policy. Res Transp Bus Manag 19:4-18. https://doi.org/10.1016/j.rtbm.2016.03.008

van Rynbach EA, Briers KE, DelGatto NJ (2018) Analysis of fuel alternatives for commercial ships in the ECA era

Žaglinskis J, Rapalis P, Lazareva N (2018) An overview of natural gas use in ships: necessity and engine supply. Periodica Polytechnica transportation engineering. Periodica Polytechnica Trans Eng. 46:185-193. doi: https:/doi.org/10.3311/PPtr.11708

\section{Publisher's Note}

Springer Nature remains neutral with regard to jurisdictional claims in published maps and institutional affiliations. 